Portland State University

PDXScholar

Summer 3-20-2013

\title{
Track I Diplomacy and Civil Society in Cyprus: Reconciliation and Peacebuilding During Negotiations
}

Elicia Keren Reed

Portland State University

Follow this and additional works at: https://pdxscholar.library.pdx.edu/open_access_etds

Part of the Other International and Area Studies Commons, Peace and Conflict Studies Commons, and the Race and Ethnicity Commons

Let us know how access to this document benefits you.

\section{Recommended Citation}

Reed, Elicia Keren, "Track I Diplomacy and Civil Society in Cyprus: Reconciliation and Peacebuilding During Negotiations" (2013). Dissertations and Theses. Paper 672.

https://doi.org/10.15760/etd.672

This Thesis is brought to you for free and open access. It has been accepted for inclusion in Dissertations and Theses by an authorized administrator of PDXScholar. Please contact us if we can make this document more accessible: pdxscholar@pdx.edu. 
Track I Diplomacy and Civil Society in Cyprus: Reconciliation and Peacebuilding

During Negotiations

$$
\text { by }
$$

Elicia Keren Reed

A thesis submitted in partial fulfillment of the requirements for the degree of

\author{
Master of Arts \\ in \\ Conflict Resolution
}

Thesis Committee:

Harry Anastasiou, Chair

Rachel Cunliffe

Aimee Clott

Portland State University

2012 
(C) 2012 Elicia Keren Reed 


\begin{abstract}
This paper examines the relationship between Track I Diplomacy and Civil Society in Cyprus. Cyprus has been a divided island for over 45 years despite numerous attempts at reconciliation on the societal level and ongoing negotiations on the diplomatic level. It was the aim of this study to examine the ways in which both civil societies and their leaders do or have worked together, if at all, to negotiate a political solution or reconciliation between the two communities. Interviews were conducted on both sides of the cultural divide and within both political and civil society sectors. Those interviews were coded, categorized, and then thematically analyzed. Findings explicate three themes that challenge the relationship and cooperation between Track I and Track II; Structural Elements, Nationalism, and International Support. Furthermore, it is proposed that the leaders must lead and support their citizens in reconciliation and peacebuilding efforts while continuing to negotiate a solution to the Cyprus problem as civil society organizations continue to support negotiation efforts.
\end{abstract}




\section{Acknowledgements}

I would like to thank, with deep gratitude, the members of my committee, for their guidance, hard work, and wisdom. I thank the Cypriots who let me into their lives. I also give many heart-felt thanks to my friends and family who supported me through this process. Thank you. 
Table of Contents

Abstract

Acknowledgment

Chapter I: The Cyprus Problem 1

Importance of This Research $\quad 3$

History of the Conflict 4

$\begin{array}{ll}\text { Cypriot Trauma. } & 7\end{array}$

Bi-Communal Peacebuilding and Reconciliation 10

$\begin{array}{ll}\text { Chapter II: Literature Review } & 17\end{array}$

$\begin{array}{lr}\text { Track I and Track II Diplomacy. } & 18\end{array}$

$\begin{array}{ll}\text { Reconciliation and Peacebuilding } & 20\end{array}$

$\begin{array}{ll}\text { Buffer Zone Incidents } & 24\end{array}$

$\begin{array}{ll}\text { Ongoing Peacebuilding Work } & 27\end{array}$

$\begin{array}{ll}\text { Nationalism } & 28\end{array}$

$\begin{array}{ll}\text { Conclusion } & 33\end{array}$

Chapter III: Methodology 35

$\begin{array}{ll}\text { Strategies of Enquiry } & 36\end{array}$

Process of Analysis $\quad 40$

Table 1: Interviewee Pseudonyms 40

Chapter IV: Discussions of Findings $\quad 42$

$\begin{array}{ll}\text { Track I Themes } & 42\end{array}$

Track II Themes $\quad 48$

Overall Findings $\quad 55$

Table 2: Comparison of Structural Elements 56

Table 3: Comparison of Nationalism $\quad 56$

Table 4: Comparison of International Influence 57

Chapter V: Implications, Recommendations, Limitations and Conclusion $\quad 58$

$\begin{array}{lr}\text { Implications } & 58\end{array}$

$\begin{array}{ll}\text { Limitations } & 60\end{array}$

$\begin{array}{ll}\text { Recommendations } & 61\end{array}$ 
Diplomacy and Society in Cyprus

Conclusion

64

Table 5: Comparison of Tracks Across the Divide

References

Appendix A: Interview Questions for Track II

71

Appendix B: Interview Questions for Track I

72

Appendix C: Human Subjects Research Review Committee Application

73

Appendix D: Human Subjects Research Review Committee Approval 


\section{CHAPTER I: THE CYPRUS PROBLEM}

The Cyprus conflict is one of several long-standing conflicts in the world. Many third party actors have been involved in various peacebuilding and reconciliation efforts on both civil society and diplomatic levels. At the civil society level, citizens from both communities have engaged in dialogue workshops and other bi-communal peacebuilding events since the 1990s. Until 2008, negotiations at the diplomatic level, from both Greek and Turkish speaking communities were not fast-paced. However, the connection between civil society efforts and diplomacy in Cyprus during periods of negotiation has yet to be fully examined within the reconciliation process of this divided society. Exploring this dynamic provides insight into the possibility for reconciliation and peacebuilding.

The aim of this study is to find out whether or not there is a connection between the role of civil society and diplomacy and the pace of negotiations and bicommunal reconciliation. The question that has guided this research is:

How do Track I and Track II relate to each other in reconciliation and peacebuilding efforts during ongoing negotiations in Cyprus?

Evidence has been examined and analyzed in an attempt to determine the degree of reconciliation practiced by both sectors, and how that has, can, or will, have an effect on negotiating a solution. The idea that civil society organizations (CSOs) have any impact on diplomatic decisions in Cyprus is a relatively new concept that has just begun to be questioned and researched. 
Track I and Track II diplomacy, as they will be defined in detail later, are two of nine tracks within the multi-track diplomacy system, conceptualized over a decade or more by Louise Diamond and John McDonald (1996). The first two tracks are of particular interest here. Track I comprises political leaders in the diplomatic world doing anything from international and domestic decision making to local and global peacemaking. Track II diplomacy, particularly well-defined and articulated earlier by Joseph Monteville (1987), is made up of Civil Society Organizations (CSOs) and nongovernmental professionals. This track is responsible for citizen engagement in peacebuilding and reconciliation work as well as bridging a gap in communication between societies, leaders, or institutions. It is important that both tracks be working together in a post-conflicted society in order to provide a sustainable space for peace (Monteville). In the case of Cyprus, it would be beneficial to know how or if these two tracks are in fact working together in a collaborative way. The other seven tracks are; Track III Business, Track IV Private Citizens, Track V Education, Track VI Peace Activism, Track VII Religion, Track VIII Funding, and Track IX Media and Public Opinion.

It would be helpful to know whether civil society or political leaders have an upper hand in directing the course of reconciliation and negotiations. If investigations can indicate which sector has more of an influence on the reconciliation process on both societal and diplomatic levels, perhaps that information can inform settlement negotiations. The exploration of these questions can be found in what follows, along with a survey of the historical background of the conflict, the level of trauma Cypriots 
have experienced, and the nature of bi-communal peace efforts. After a review of the literature, I present the methodology used, my findings from semi-structured interviews conducted in Cyprus, a discussion of these results, and recommendations for further analysis and action.

\section{Importance of This Research}

The history and memories of the Cyprus conflict play a role in determining and framing its peaceful future and are influenced by diplomatic decisions and involvement as well as civil society participation. Diplomacy has fluctuated between embracing and thwarting reconciliation between the communities. That inconsistency affects civil society peacebuilding initiatives. In addition, CSOs face multiple challenges that hinder any long-term success in peacebuilding. The first question arising from these facts is: Does the opinion of the public drive political initiatives or do diplomatic efforts drive the public's perspective on, and promotion of, reconciliation? The second question is: Does one or the other determine the course of negotiations and reconciliation efforts? My preliminary, abstract, and unpolished question before beginning this research was, which comes first, the chicken or the egg - does diplomacy lead the peace process or does civil society?

The roles of diplomacy and civil society in peacebuilding are important because both sectors help to inform the environment of reconciliation and negotiations. Looking into the dynamics of the relationship of civil society efforts and diplomacy during negotiations lends an insight into what helps shape the context of reconciliation and what may bring the Greek and Turkish Cypriot communities together. Gathering 
perspectives from different sectors of the two communities provides insight into Cypriot sentiment. Although the number of informants in this research study may be small in comparison to the population, their voices represent valuable opinions and beliefs across the island. These voices provide insight into the post-war culture of the island, which then reflects the flow of reconciliation and negotiations. The more we know, the more we can do.

\section{History of the Conflict}

Cyprus is a $2^{\text {nd }}$ world country and had been under foreign rule for centuries until achieving its independence on August 16, 1960 from Britain. Located south of Turkey, just miles away from Middle Eastern countries like Syria, Egypt, and Iraq, and off of

the Aegean Sea next to the Greek islands, Cyprus has been a hot commodity. The island has been under foreign rule for centuries mainly because its strategic location has provided a perfect staging port for empires, travelers and traders since ancient times. Since its independence from Britain in 1960, intercultural conflict has been the status quo, resulting in war, invasion, citizen displacement, trauma, hate for the other and the division of the island. Currently, the island experiences negative peace. While both sides are not at war in a violent physical manner, Turkish speaking Cypriots in the north and Greek speaking Cypriots in the south have been divided into two communities by a physical barrier called the green line or buffer zone, manned by UN personnel. Hatred for the "other" still widely exists and a diplomatic solution has never been reached.

Reconciliation on a societal level and achieving a settlement agreement on the diplomatic level in Cyprus would be beneficial in several ways. First, while it may take 
several generations, demonization of the other would dissipate and peace would ensue, allowing the societies to live as they did before; together. Secondly, the TRNC would cease to exist and those in the North would eventually receive EU benefits. This would create an entire economic shift where wealth would be distributed in a more even way than it is currently, mainly in the South. Lastly, Cypriots would have the chance to be appropriately represented not only locally, but internationally as well. This would mean the entirety of Cyprus would have one voice after some time and there would be more of a sense of cohesiveness.

After Great Britain ended the Ottoman Empire rule in 1878, Cyprus eventually came under the ruling of the British Crown in 1925 (Wolleh, 2001). The Zurich Agreements were the first steps toward independence from Britain in February of 1959. Several diplomatic solutions on power sharing were discussed and signed at that time, called the London agreements, which consisted of nine documents. Three of those documents particularly focused on fundamentals of the structure of the new Republic of Cyprus, a Guarantor Agreement between Cyprus, Britain, Greece and Turkey, and a "Treaty of Alliance" between Cyprus, Greece, and Turkey (Fairfield, 1959). Appointed in 1960 were Greek-speaking Cypriot President, Archbishop Makarios III, and a Turkish-speaking Cypriot Vice President, Dr. Fazil Kutchuk. Fighting broke out between Greek and Turkish Cypriots December 22, 1963 after President Makarios proposed several revisions to the new Constitution that were considered a threat to Turkish Cypriots, already a minority in Cyprus (Brands, 1987). Violent struggle and bloodshed ensued. Around 25,000 Turkish Cypriots were displaced 
at this time, forced into enclaves, along with 700 Greek Cypriots who fled their homes seeking protection (Gürel \& Özersay, 2006). Cypriots called on Greece and Turkey for help while Britain, a guarantor power, organized negotiations in January the following year in London. The London conference failed as each side preferred to manage the situation within Cyprus without external support. Cypriots maintained hatred for one another while diplomatic meetings, conferences, letters, and threats of war were sent to the Cypriot Administration. Turkey was ready to invade the island to protect Turkish Cypriots while Greece was ready to fight back and deliver enosis, the political union of Greece to Cyprus. The UN was eventually asked to intervene March 1964, which calmed the situation until June, when another war scare emerged (Brands, 1987, p. 354). This scare was also averted, but the Cyprus question was nowhere near a solution. Retreating into enclaves, the Turkish-speaking community sought shelter, stopped paying taxes, and withdrew from government activity. The Green Line was created to divide the two communities; Makarios was seen mainly as a Greek Cypriot President while Kutchuk headed the Provisional Turkish Administration until 1973, being replaced by Rauf Denktash (King \& Ladbury, 1982). The Cyprus situation had become an international problem, with the involvement Greece, Turkey, Britain, the United States, Russia, and Egypt.

President Makarios was overthrown in a coup led by the Greek Military Junta in 1974 and replaced by Nicos Sampson. Very shortly thereafter the Turkish military invaded the island. Both Turkish, Greek, and Cypriot sides either held their prisoners for exchange, or killed them without question. Both sides of the divide were guilty of 
killing innocent citizens in their homes and villages based on their ethnicity. Many Cypriots were able to flee to the mountains for protection when they received word of the coup and invasion. Some sought protection at the British bases on the island. Many villages were destroyed and most Cypriots, Greek and Turkish speaking, lost their homes and loved ones.

Due to the geographical placement of Turkey and Cyprus, Greek-speaking Cypriots living in the north fled to the south as Turkish troops landed on the northern tip of the island. The United Nations facilitated an agreement between the two sides. Over the course of a year, between 1974-1975, UN convoys escorted about 631,778 Cypriots to either side of the island (King \& Ladbury, 1982). Turkish-speaking Cypriots in the south were moved to the north and any Greek-speaking Cypriots that were still in the north were escorted to the south. To this day, Turkish Cypriots consider 1963 as traumatic while Greek Cypriots the war of 1974 the same. The Turkish army still maintains a presence in the northern part of the island with up to 40,000 troops stationed there (Liang, 2008). The Turkish Republic of Northern Cyprus was established on November 15, 1983 by the Turkish Cypriot Administration but was and is considered invalid by the Security Council (UNFICYP, n.d.). The south is a member of the European Union, is known as the Republic of Cyprus and claims legitimacy over the entire island.

\section{Cypriot Trauma}

During the months of invasions and displacement in 1974, thousands of Cypriots went missing; many lost their lives, and most Cypriots lost their homes and belongings. 
It is important to note that these homes, and the land on which they sat, for many Cypriots, had been in their families for generations. This is important because these are the sentiments that help maintain the conflict today. Resentments and grief that come from losing a home and community still exist.

The months during 1963 when Turkish Cypriots were forced into enclaves and Greek Cypriots were displaced as a result, were traumatic times for both communities. Turkish Cypriots consider this experience as agonizing as the Greek Cypriots regard the experiences in the war of 1974. The intercommunal killings that happened in both events added to the fear, distrust, and hatred for each other. For example, Loizos (1988) writes of a Greek Cypriot man called Kajis who was a member of EOKA VITA, an underground organization that, with the help of the Greek army, overthrew Makarios. In 1974, Kajis experienced his fellow villagers and officers being ambushed and shot to death. Following this, he apparently lost mental and physical control of himself and "burst into a house containing seven Turkish Cypriots, including several women and at least one child. He machine-gunned them all to death" (Loizos, 1988, p. 641). Although there were no combatants, Kajis explained that he was in a war and only afterwards did he notice the child. In his account, he says "What harm had it done, you ask? It was Turkish. They'd shot my fellow-villager, they'd shot my captain, so I'd shot them" (as quoted in Loizos, 1988, p. 641). While this account may speak to many attributes of war and the atrocities that ensued, it is an important account of traumatic incidents that scarred both Greek and Turkish Cypriots. This shows how trauma causes dehumanization of the group that is blamed and justifies actions, which, under normal 
circumstances, would have been rejected outright. There are many more stories in this vein that illustrate the pain and horror Cypriots experienced before the division of the island. The fact that a physical barrier divided the island after these horrendous acts indicates unresolved anger and pain that still exists. However, being physically divided from those that have come to be hated does not allow a space for mourning, closure, communication, or for the process of reconciliation. The more space there is from a contentious situation, the more tension is created because communication is cut off and the opportunity to resolve the problem has been taken away. There is a barrier instead of a space for reconciliation.

Cypriots were divided for decades, but April 3, 2008 marked a major step in negotiations with the opening of the Ledra crossing, which is discussed in more detail below, but is important to note now. Cypriots were not able to see how the other community lived for 34 years, nor were they able to see the faces of those that had since been deemed as the "Other" (UN Security Council, 2011). Opening the checkpoint on Ledra Street sparked reactions that revealed the pain that still exists from the events of 1963 and 1974 within both Turkish and Greek Cypriot lives. Children who had been driven from their homes were now adults with their own families. Many crossed the checkpoints with their families to face painful memories. Some crossed over to make peace with the "other" and within themselves. Some have never crossed the Ledra checkpoint out of fear of the other and because of their traumatic histories.

Those who were young during the 1963 events and lived through the invasion of 1974 have experienced over 40 years of pain and growth alike. Their children have 
experienced it second-hand. They have heard the horror stories from their parents. For many, the pain of the war has left its mark and has been passed on in intergenerational trauma. This part of civil society has influence over future change and it is important that the pain of their parents is not carried on in an unconstructive way, especially through diplomatic means such as local policies or by a lack of negotiation. The youth of the island are an essential factor to solving this problem. Some may become diplomats or perhaps strong voices in the reconciliation process. One can only imagine that the stories of their parents are more influential than history books; seeing a parent cry or hearing hate in his or her voice due to past experience of the war is stronger than international opinion, diplomatic negotiations, or religious influences.

\section{Bi-Communal Peacebuilding and Reconciliation Successes and Challenges}

In an effort to bring peace to the island before the south of Cyprus entered into the European Union (EU), Cypriots were asked to decide by referendum on unifying the island in 2004. General Secretary of the United Nations at the time, Kofi Annan, drafted the referendum. The referendum, known as the Annan Plan was officially titled "The Comprehensive Settlement of the Cyprus Problem.” It consisted of several power sharing agreements and outlined the new state and new Constitution. This plan framed agreements for a bi-zonal Federation; the United Cyprus Republic. The Annan Plan outlined new property laws and compensation dues, constituency representation, the demilitarization of the United Cyprus Republic, single Cypriot citizenship, fundamental rights, what the new flag would look like, and other functions of a unified Cyprus (Annan, 2004). 
The resulting vote on the referendum was surprising; Turkish-speaking Cypriots voted for the plan at $64.9 \%$ and the Greek-speaking Cypriots voted it down by $75.8 \%$ (Anastasiou, 2009). This was surprising because a prevailing view had been that Turkish-speaking Cypriots would not want to negotiate a settlement of any kind since their goal was still partition instead of a bi-zonal Federation.

Cyprus was still divided when it entered the European Union a month later (Anastasiou, 2008). However, the TRNC is not a part of the EU. This event created even more of a division between the communities because the south gained European Union benefits while the north still did not enjoy international recognition and was economically weaker. Turkish-speaking Cypriots recognized a major power imbalance, which then spurred paranoia and further distrust between the two communities. Not only did the Greek-speaking Cypriots vote no on the Annan Plan, they now had the support of the European Union, which meant funding for infrastructure, economic prosperity, modern retail advantages, and a legitimized voice in the international community. For the north, this meant that all power, money, and voice went through and came from Turkey instead of local Turkish Cypriot leadership.

With such close ties with Turkey, Turkish-speaking Cypriots began seeing many Turkish natives moving to northern Cyprus, making Turkish Cypriots a minority in their own country. This ultimately meant that Cypriots living in the north were reliant upon Turkey politically, economically, and militarily. Due to the benefits of being in the European Union, Cypriots in the south were able to act more independently than their northern counterparts, politically, economically, militarily, and even when it came to 
higher education. There are capacity building measures supported by the UN, such as the Millennium Development Goals, set to build up infrastructure of northern Cyprus. Nevertheless, these differences created more challenges to peacebuilding efforts, and continue to inform views of the "Other" across the cultural divide today.

The most promising steps in diplomatic bi-communal communication were initiated on March 21, 2008 when Turkish-speaking Cypriot leader Mehmet Ali Talat and Greek-speaking Cypriot President Demetris Christofias agreed to launch fullfledged negotiations. By the 23rd of March, "the two leaders reaffirmed their commitment to a bi-zonal, bi-communal federation with political equality," (UN Report 610,2009, p. 1) a partnership that would speak with one voice internationally but would have both Turkish and Greek speaking Cypriot states, which would have equal status. Within four months, the leaders set in place six working groups created to review the chapters to be negotiated and seven technical committees that would focus on confidence-building measures aimed at enhancing the relationship of the communities (UN Report 610, 2009). Actual negotiations between the leaders and corresponding representatives took place in September 2008 through the good offices of the United Nations. From May 2009 to December 2009, leaders met 27 times, which lead to the complete discussion of all six chapters of the negotiation framework; governance and power-sharing, security and guarantees, property, territory, European Union-related matters, and economic matters (UN Report 610, 2009, p. 3). While negotiations were fast-paced compared to those in the past, a settlement was never fully negotiated and many chapters still remain complicated and unsettled. 
The property issue is especially intricate and complicated. Not only are property laws in the north unacceptable to the south and always in debate, but the historical emotions that come into play carry much weight in the lives of those that were forced from their homes during the war. This plays a major part in the reconciliation process between civil societies and the negotiation process between leaders because both communities experienced emotional and physical loss.

In 1963, Turkish-speaking Cypriots were forced to flee their homes and live in very small enclaves. In 1974, Greek-speaking Cypriots were forced to leave their homes in the north and move to the south. Both communities experienced the loss of homes that had perhaps been in their families for generations. Today, many Greek-speaking Cypriots live in former Turkish-speaking Cypriot homes and vice-versa. Furthermore, property in the north that once belonged to Greek-speaking Cypriots has been bought by foreigners seeking vacation homes, or it has been bought and built on by those from Turkey. This makes it harder to "return" property to those who lost it decades earlier. However, many Cypriots maintain that property lost during the war is still theirs and that they should either receive compensation for their loss or have it returned to them. But when checkpoints opened and Cypriots were allowed to cross at will and visit their old homes, many vowed never to return due to the harassment they experienced across the divide.

Following a commitment to sit at the negotiation table, Cypriot leaders Christofias and Talat agreed to open a checkpoint in old town Nicosia on Ledra Street on April 3, 2008 (UN Report 603, 2010). The buffer zone, or 'green line,' as it is also 
called, stretches from east to west across the island, and is a physical barrier made of barbed wire, sandbags, old fencing, and warning signs. The UN and Turkish Cypriot military or Greek Cypriot military, on their respective sides and stations, man the green line. There is a total of six checkpoints set up along the buffer zone that allows people to cross from one side to the other. If a visitor is crossing the checkpoints at Ledra from the south into the north, he or she will pass through the buffer zone, where old buildings may be seen riddled with bullet holes, foliage growing randomly throughout its infrastructure, and collapsing roofs. At a row of plastic-made covered booths a visa is completed which comprises a slip of paper containing name, nationality, and ID or passport number. Turkish Cypriot military official stamps the slip and the visitor can go through. Upon returning from the north, the visitor stands in an opposite line to have the visa paper stamped showing exit. The buffer zone is again traversed until reaching the Greek Cypriot checkpoint, whereupon the visa stamp is checked. At no time do the Greek Cypriot police stamp passports or visas, mainly because they refuse to acknowledge or legitimize any laws in the north.

Laws governing the movement of people and goods were relaxed after 2003, but opening the Ledra Street crossing signified free movement between communities. This also provided an increased emergence of bi-communal communication, more civil society organization work, and traffic between communities.

In April 2010, Dervish Eroglu replaced Talat in leadership in the TRNC. Eroglu is a member of the right-wing National Unity Party (UBP) and is known as a hardliner. Although critics feared this would mean an end to negotiations, Eroglu 
assured the public during his Presidential victory speech that he would not walk away from negotiations (Yilmaz, 2010). Between 2008-2010, both leaders met a total of 88 times (UN Report 603, 2010). However, between March 2011 and October 2011, the two leaders had only met 17 times. The meetings, states UN Secretary-General Ban KiMoon, have "been spent in clarifying positions instead of moving towards convergences" (UN Report 498, 2011, p. 3) although many discussions have made some strides. Both leaders have turned to technical experts, as suggested by the Secretary-General, on the issue of property, but have yet to return to formal negotiations on the matter. The Secretary-General reports various peacebuilding institutional openings in Nicosia in his Report on Cyprus. These include Cyprus 2015 and ENGAGE, which are supported by the UN Development Program (UNDP) and the "Home for Cooperation" opened by the Association for Historical Dialogue and Research (UN Report 498, 2011). Cyprus 2015 and ENGAGE are Cypriot CSOs that work closely with other CSOs in support of the peace process. The "Home for Cooperation" provides a space for bi-communal dialogues, education, and research. In his report (2011) the Secretary-General calls on both leaders to "engage civil society in the task of reaching a comprehensive settlement" (UN Report 498, 2011, p. 4) and to keep civil society efforts towards peace in mind during negotiations, thereby noting the importance of civil society's involvement in peace work across all levels of diplomacy.

The history of Cyprus is abundant. The past 44 years have been marked in continuous conflict, peppered with peacebuilding and reconciliation efforts from both communities. The following section explores literature exemplifying aspects of what 
communities experience throughout its recent history and efforts that have been made to rectify cooperation between communities. 


\section{CHAPTER II: LITERATURE REVIEW}

Peacebuilding institutions, such as the Home for Cooperation in Nicosia, are a good example of Track II diplomacy. The study of the relationship between Track I and Track II diplomacy in Cyprus is important in the peacebuilding process because collaboration between the two could produce powerful results. In the course of the Cyprus conflict, many diplomatic efforts have been made both domestically and internationally to enhance different forms of peaceful unity (Anastasiou, 2008). Negotiations have begun and have been halted, fast-tracked, and revisited through out the years. There is substantial literature on the Cyprus conflict, focusing on aspects of political science or international relations in peace journals (Anastasiou, 2008;

Gürkaynak, 2007; Michael, 2007; Turk, 2006; Wolleh, 2001). However, there are many more areas to explore within the Cyprus conflict. These areas include the socio-dynamic of civil society's willingness to cooperate and work together to make peace with the other community, the impact on civil society after having entered into the European Union, and the psychological effects of Cypriot nationalism. Beyond these areas are the ways in which diplomacy possibly plays a part in civil society's decision in directing its efforts in peacebuilding.

There are different levels of diplomacy at work in Cyprus. The majority of work that is being done is located in the divided capital of Cyprus, Nicosia. This is where the bulk of non-governmental and civil society organizations (CSOs) exist. The capital is also where both leaders are based. 
This research focuses on Track I and Track II diplomacy. Other important literature explored here is about reconciliation, peacebuilding, and nationalism. The following literature review describes core aspects of Tracks of diplomacy as well as characteristics of the atmosphere in Cyprus.

\section{Track I and Track II Diplomacy}

Diamond and McDonald (1996) have defined nine tracks of diplomacy within a multi-track system. Track I Diplomacy is "the world of official diplomacy, policymaking, and peacebuilding as expressed through formal aspects of the governmental process" (p. 4) where diplomats both internationally and domestically play a part in creating the political world, as we know it. This may be in the form of international treaties, third party interventions, domestic policy making, and any other official acts of political affairs. Track I is an example of directly influential politics.

A number of authors have talked about different Tracks of Diplomacy. Diamond and McDonald have the most comprehensive definitions but Track I and Track II are the most important in this paper. Track II diplomacy, previously defined by Joseph Monteville (1987), refers to interactions between groups in nations that help develop strategies in order to help resolve conflict, mainly through nongovernmental professional work. According to Esra Gürkaynak (2007), Track II diplomacy is parallel to unofficial diplomacy work, referring to an assortment of unofficial forms of conflict resolution actions on a non-governmental level. Track II work relies on a transformational worldview where basic human needs set the agenda, where collaboration is key and international relations is more than just crisis management 
(Diamond \& McDonald, 1996). Those engaged in Track II work come from various backgrounds and fields; some are from the Track I field, some are theoreticians or practitioners, some are experienced activists or educators, and many key players have higher education degrees. Diamond and McDonald explain that Track II engages in a wide range of activities from workshops to dialogue groups and from institution building to communication liaisons. This work could stem from non-profit organizations and CSOs that focus their work on local peacebuilding or bi-lateral relationships between countries or communities on a continuous basis. The idea is to bring together members of the community who will be able to communicate, transfer, and support creative and sustainable approaches to reconciliation and peacebuilding efforts within the general public (USIP, 2003).

A. Marco Turk (2006) was responsible for training segments of both societies in Cyprus on conflict resolution methods from 1997-1999 and in 2003. Track II, according to Turk (2006), involves NGOs and ordinary citizens. Turk (2006) also states that "this level can be effective as a connector between Tracks I and III," (p. 222) where Track III contains advocates that are community and business-based. This connection helps to support peaceful resolution approaches and exercise co-existence across divides without relying solely on the political elite (Turk, 2007).

An essential example of Track I diplomacy in the Cyprus case is the Annan Plan from 2004. While the conflict is, as Michael (2007) writes, a linkage of politics operating outside the diplomatic tracks but on five levels: local, national, subregional, regional and international, they all run into the same direct politicization of key issues. 
The Annan plan, while negotiated on a Track I level, was turned down on Track II and III levels. This could very well be an example of how a relationship between the tracks could be developmentally and structurally beneficial. The work being done by Track II, especially in the Greek Cypriot community, was not corresponding to the negotiation process nor was the "psychology of the political situation it was seeking to remedy" (Michael, 2007, p. 590). Thus, the Annan Plan was not seen, nor was it communicated, as a beneficial option for the Greek Cypriot society, which voted it down in majority.

\section{Reconciliation and Peacebuilding}

Peacebuilding work being done by Track II in Cyprus is not fully supported by Track I. This is exemplified by the lack of public acknowledgment from leaders surrounding any peacebuilding efforts, such as the opening of peacebuilding institutions. The more both tracks involve and support each other in the peacebuilding process, the more reconciliation has the space to develop. Reconciliation is a process of restoring relationships that have been alienated due to conflict. Just as in interpersonal conflicts, reconciliation on a societal level has a history of relationships, perpetrators, victims, and beneficiaries (de la Rey, 2000). Bringing the communities together is vital in bringing past actions, feelings, traumas, and injustices into the reconciliation process. Without acknowledging the past, it is hard, if not impossible, to move forward. Conflicts that last for a long time or that is still in existence do a lot of damage to societal structures and society's members.

According to Lederach (1997), there are four elements in the reconciliation process: truth, mercy, justice, and peace. Each element has a unique role in the 
reconciliation process in order to really promote reconciliation on multiple levels. Psychologically, Bar-Tal (2000) writes, reconciliation "refers to a societal-cultural process that encompasses the majority of society members, who form new beliefs about the former adversary, about their own society, and about the relationship between the two groups" (p. 356) and is not necessarily a formal process encompassed within the conflict resolution process. It is a psychological process because it involves changing "the well-entrenched conflicted ethos" which then "helps the society to cope with the adversary but at the same time fuels the conflict and constitutes the fundamental obstacle to its resolution" (p. 357). Beliefs about societal goals, the adversary group, the ingroup, intergroup relations, and peace may need to be changed throughout the reconciliation process in order to replace the conflicted ethos to that of a peace ethos (Bar-Tal). These beliefs inform the kinds of changes that need to, or that do, change throughout reconciliation.

Peacebuilding is a process that involves both societal and political members of a community. Secretary-General Boutros Boutros-Ghali (1992) stressed the need for peacebuilding work in Agenda for Peace, which spoke to the need for human rights laws and the need for developing capacity, along with peacekeeping work the UN did. This is the first time that the term 'peacebuilding' was fully introduced into UN work. Peacebuilding is a term that, in the context of Conflict Resolution, was introduced by Galtung (1976) in an essay where he defines the work of the UN as "dissociative" in comparison to "associative" where immediate issues of violence and issues of structural violence are handled directly. The associative approach deals with social relations 
between parties in conflict as well as the "infrastructure of equity," providing a way to resolve conflict without the use of violence (Galtung, 1976, p. 297).

Oliver Wolleh (2001) conducted a case study, utilizing a grounded theory approach, on the development of the bicommunal Conflict Resolution Trainer Group in Cyprus between 1994 and 1997. The Trainer Group developed through several stages in its attempt to gather a unified group of Greek and Turkish-speaking Cypriots to initiate dialogue and promote peacebuilding through bicommunal reconciliation activities. Participants consisted of thirteen Greek and Turkish Cypriots who were trained between 1994 and 1995. Benjamin J. Broome, a Fulbright Resident Scholar, facilitated the activities. Obstacles for peacebuilding, developing a cohesive and unified vision statement, and developing project ideas were the first three phases of the workshops employed. Eventually, bicommunal workshops and facilitating groups were led in part by these participants, creating local, internal actors for the peacebuilding process within Cyprus. Dialogues were initiated, and for the first time, participants listened to points of view across the cultural divide by engaging in 'deep dialogue' which "was characterized by the steps 'listening - understanding - acknowledging"” (Wolleh, p. 18). There were many obstacles within the structure of the dialogue groups, but the evolution of the Trainer Group exemplified that "internal actors are able to establish themselves in the same way as effective, neutral facilitators and can take on a number of Third Party functions" (Wolleh, p. 45). The major challenge, Wolleh concluded, was the presence of American trainers or facilitators in workshops. He found that "the lack of trust is unconnected to the trainer's personality or the method 
applied, but rather with the worry of the participants that their expressions via the US network and the American negotiators become part of the official process of negotiation,” (p. 46). Despite the existence of distrust, however, the development of bicommunal peace building activities paved the way for future reconciliation efforts; an important stepping-stone in this divided society.

Many different factors found within conflicts influence civil society. The overarching mentality, emotionality, reactions, responses, and intention of organized mobilizations that spread across civil society differ according to circumstances. The nature of politics becomes a frame of reference for the conflict environment, warranting certain attitudes from civil society. Thus, the nature of politics incites different societal incentives to generate a movement across different sectors in society (Marchetti \& Tocci, 2009, p. 201).

Currently, literature about civil society and its actual impact on diplomacy in Cyprus does not exist. However, discussions of civil society roles have existed within philosophical dialogue for centuries (Marchetti \& Tocci, 2009). The literature examines how civil societies in both global and domestic contexts are independent agents for change. At the same time, civil societies are dependent upon the structures that exist. Civil society interacts with the state; they influence each other simultaneously (Marchetti \& Tocci, 2009). The multi-tracks of diplomacy can be seen working interactively as such, within their respective influences, especially in societies that have suffered a conflict and are trying to reconcile on several levels. It is as if it is impossible to reconcile on one level without reconciling on another. Therefore, all diplomatic 
tracks influence and can be influenced by each other. Because there is a lack of literature in relation to Cypriot civil society and diplomacy, it is hard to say whether or not they are in fact influenced by each other in Cyprus.

The ethnic polarizations of Greek and Turkish communities in Cyprus were and have been a result of Track I diplomacy efforts. Track II work can be seen within Cypriot society since 1992 when bi-communal peace efforts were initiated through third-party non-state organizations under the auspices of the United Nations, United States, European Union, or other independent contributions (Katrivanou, 2009).

\section{The Buffer-Zone Incidents}

Scholars Benjamin Broome, Harry Anastasiou, Maria Hadjipavlou, and Bulent Kanol have been active in peacebuilding groups and have initiated bicommunal projects on the island since the 1980 s. They combined their efforts to create a scholarly account of a contentious event on August 11, 1996 in Cyprus in an article "Opening Communication Pathways in Protracted Conflict: From Tragedy to Dialogue in Cyprus" (2012). A group of Greek-Cypriot motorcyclists in the Cyprus Motorcyclist Federation, organized an "anti-occupation" rally, protesting the presence of Turkish troops in the north (Broome, et al). They planned to gather at the Dherinia crossing point, on the eastern edge of the buffer zone. Many Greek-Cypriot political leaders openly endorsed this plan along with banks and cooperatives, which opened accounts to gather money in support of this cause. At the same time, "the UN warned that the possible entry of non-authorized persons into the buffer zone would constitute a violation of the cease-fire agreement" (p. 7) that could prove to have a dangerous 
outcome. UN Secretary General at the time, Boutros Boutros-Ghali intervened the day before the main event, which then led to an appeal from the president to the Cyprus Motorcyclist Federation to discontinue their plan. The organizers agreed to cancel the event and instead hold a rally in Nicosia. However, because there had been so much invested in preparations for the rally, some motorcyclists and others in vehicles arrived at the checkpoint as previously planned.

Extremists in the north had prepared their own rally in anticipation of a confrontation at the buffer zone. Members of the Gray Wolves, a right-wing nationalist organization from Turkey was among this crowd. There were Turkish-Cypriot leaders asking Turkish-Cypriots not to participate, but their voices were muted by top-level Turkish-Cypriot and Turkish nationalist leaders, determined to "teach the GreekCypriots a lesson" (Broome et al, 2012, p. 8). Both sides of the buffer zone were lined with extreme nationalists ready to confront each other. Each group consisted of both civil and political leaders who were from an older generation along with mobilized youth of the island. Many Greek-Cypriot demonstrators pushed through the buffer zone, throwing rocks at soldiers and police in the north. Demonstrators in the north also pushed through and fighting broke out. Both police forces and UN peacekeepers were overwhelmed. A Greek-Cypriot became entangled in the barbed wire of the buffer zone, and was beaten and killed. Videotape captured a Turkish-Cypriot officer participating in the beating and this videotape was immediately broadcasted island-wide (Broome et al, 2012). Three days after the funeral of this victim, demonstrations occurred again at the Dherinia crossing. This time, a Greek-Cypriot ran into the buffer zone, climbed the 
flagpole flying a Turkish flag, and was shot by the Turkish military. This was caught on tape again and broadcast across the island. Nationalist rhetoric, hard-line views, and anti-Turkish sentiment filled the airwaves. Greek-Cypriots pointed to the 'barbaric' nature of the Turks while Turkish-Cypriots reinforced their desire for a unitary state and argued that the presence of the Turkish military was necessary for protection. Neither side felt they would be able to live peacefully together. According to Broome, et al., these incidents can be seen as an example of protracted interethnic conflict with features of ethnocentric nationalism. Conflicts such as this are incredibly complex due to their "negative dynamics that are self-perpetuating and extremely difficult to resolve" (p. 10).

This incident incited further hate and nationalist sentiment, which created an opportunity to bring communities together and discuss the events. Seeing the bulk of their past peacebuilding work evaporating before them, Broome, et al, made strides to create a bicommunal gathering in order to facilitate peaceful dialogue surrounding the buffer zone incidents, six weeks after they occurred on the International Day of Peace (Peace Day). Peace Day is a holiday in which those who have made efforts to promote peace are honored annually. These dialogues existed because Track I diplomacy was utilized and it legitimized the need for a peaceful gathering, thereby engaging Track II. In attendance were about 150 people, who included UN personnel, and ambassadors from most embassies on the island. In later events attendance was over 1000 with both Greek and Turkish Cypriots from Track I and Track II (Broome, et al).

These bicommunal events resulted in a reclaiming of the belief that diplomacy could impact civil society efforts in peacebuilding, reducing some of the burden that the 
incidents had created by using political influence behind the scenes to cut through hardliner tape in order to produce powerful peacebuilding events. These bi-communal events continued through the end of 1997, challenging nationalistic mentalities. They "embodied the hope of a new post-nationalist paradigm that pointed to the replacement of nationalist animosity through interethnic friendship, and the expansion of people's sense of community" (p. 29) by coming together across the dividing line following such hostile incidents. Gaining support from diplomats in order to obtain permission to create a peace process around this incident allowed for a space in which civil society could become involved. This is one example of the influence the relationship between Track I diplomacy and civil society has on reconciliation in Cyprus.

\section{Ongoing Peacebuilding Work}

In the early 1990s, members of civil society in the peace process provided "a gradual awakening and mobilization" (Anastasiou, 2008, p. 35) that occurred despite an overwhelming environment of rapprochement at the diplomatic level. Dr. Harry Anastasiou $(2002,2008,2009)$ was active in this peace process at that time and mobilized Cypriot citizens despite diplomatic impasse and nationalist rhetoric. Citizen identity and social mobility in the past were redefined "in actions and attitudes that empowered the development of a public political culture" that created "active participation in the building and the forging of sustainable relationships of interethnic cooperation and power sharing" (Anastasiou, 2008, p. 41). This resulted in the creation of several bicommunal peace groups that focused on various areas of peacebuilding and reconciliation on a Track II level. These groups persevered despite ongoing attempts 
from Cypriot nationalists and the Administrations to break up the meetings held in the buffer zone. Civil society mobilization in Cyprus from that point on "provided a viable model of how citizen-initiated peace building constitutes a vital dimension of civil society" (p. 40) and what that peace process could look like with perseverance.

This movement challenged nationalists in both communities, but it also gave rise to new relationships with those on the grass roots level and with political leaders. According to Lederach (2002), the "peace constituency is a vital sociocultural resource and catalyst of conflict transformation" (as cited in Anastasiou, 2008, p. 42) and is necessary in the conflict resolution process, especially in divided societies. The ways in which civil society urged political leaders to consider peacebuilding methods in diplomacy were carried under the radar and included informal talks where "conflict resolving ideas and options" (Anastasiou, 2008, p. 44) were shared that had been developed in think tanks with the support of international organizations. This strategy created a shift in attitudes and behaviors from the societal level to the diplomatic level, a positive change even if it only included a minority of the population.

\section{Nationalism}

The concept of nationalism is vast in its definition and research discipline. According to Paul Stern (1995), there are three classes of nationalism; a modified primordialist approach, an instrumentalist account, and a constructionist approach. The modified primordialist approach emphasizes an individual's emotional binding to an ethnic group. The instrumentalist approach values nationality and ethnicity for the purpose of mobilization or organizing a collective based on common interests. The 
constructionist approach stresses the social creation and nature of nationality and thereby of shared values. The constructionist approach also points out that "national consciousness" rises out of crisis and is then "brokered" by intellectuals who create identities and perceived interests, or even languages (Stern, p. 218). Stern also notes that these three perspectives lend insight to the explanation of national loyalty and nationalist sacrifice; there are deep emotional and normative components that are socially constructed, manipulated by leaders, and that overwhelm loyalty to any other social groups. Nationalism is strongly rooted in self-interest and therefore, the interest of the nation, because that is where social construction and strong emotional ties exist.

Nationalism, according to George Orwell (1945), is "the habit of identifying oneself with a single nation or other unit, placing it beyond 'good' and 'evil' and recognizing no other duty than that or advancing its interests," (p. 362). According to Anderson (1995) and Hobsbawm (1994) a division is created between peoples and states and that division creates an "imagined community" (Anastasiou, 2002, p. 582). There, the community "is couched in an ethnocentric construct of history, highlighted by wars and revolutions," which are then prolonged because of such separations, both physically and artificially (Anastasiou, 2002, p. 582).

What follows draws heavily on literature from Vamit Volkan (1985), a Turkish Cyptriot scholar of nationalism. The nationalist is devoted to the state, engaged in a constant struggle to secure power for the state, and is unsympathetic to any suffering experienced by enemies. Obsession with allegiance to the state, the narcissism of the group, and indifference to reality are other characteristics of nationalism. Volkan further 
describes the nationalist as having "suitable targets of externalization" (p. 231) on which build a foundation in order to create enemies and allies alike. These targets of externalization are the result of continuous attempts to protect our sense of self and to regulate our selves. According to Volkan, we externalize that which we do not understand or like within ourselves. From a young age this externalization is in the form of a "transitional object" like a blanket or teddy bear, which is more important than anything else; even the mother. This object gives the child the illusion of an external reality that matches his or her capacity to create and helps the child in "developing a sense of reality and establishing his own individual identity" (p. 234). The importance of nationalism in this psychological context is that in the nationalist's mind, it is through the development of self-identification that "one assimilates the images of the other into one's own self, becoming like the other in many ways" (p. 237).

The 'other' is a term used to signify an enemy, a 'them' versus 'us' mentality, and a side other than your own. The other is the enemy; the one nationalists are fighting against in order to protect the nation. Volkan says that the enemy is actually the projected negative self, the externalized target. Externalization may be in the form of familiar foods, languages, flags, etc., which add to an effect of conceptualizations like ethnicity and nationality. The ego identity can grow in a positive way with each value and any boost in self-esteem but, for example, an attack on the group it identifies with, will reduce it and make the group more cohesive as a result. The danger is that group members "may turn to shared targets not only to patch up their disturbed sense of self but also to establish grounds upon which to reunite for mutual support and strength" 
(1985, p. 241). Volkan (1985) retells the story of the Greeks and Turks in Cyprus as a case of shared suitable targets of externalization in the form of parakeets. When in 1963 the Turkish Cypriots were forced into enclaves, they were surrounded by enemies and trying to survive a time of hardship. In order to boost their emotional survival, they raised thousands of parakeets in cages, caring for them in homes and shops. These birds became the externalized public emblem of their "imprisoned selves" during that time. And, as Volkan writes, "as long as they could nurture the birds, they were able to regulate their individual senses of self, and to maintain the kind of hope that kept their group cohesive" (p. 242). Once the Turkish Cypriots were moved out of enclaves, apparently the parakeet phenomenon ceased to exist, without mention or reason.

As John Mack (1983) suggests, the group that one identifies with gives life meaning and frames values. If a person's group experiences injustice, that group is threatened and there is a risk of feeling inferior to those deemed as the other, that have caused the initial threatened feeling. The other is considered to be an enemy and a cause that may eventually become something to fight against just as their group is a cause worth fighting for. According to Mack, nationalism is tied to three central domains of self-feeling: belonging, survival, and self worth. The need to belong is essential to all humans. The nation is essential to this sense of belonging, especially in symbols such as a passport or flag. Since the nation is supposed to protect its people, the function of a national or sub-national group is also to provide security to its people. National leaders tend to play on the fears surrounding security in order to mobilize those that would die for their nation, which then leaves little room for "sorting out realistic dangers from 
worst case scenarios that are the outgrowth of primitive fears or profound ignorance of the actual intentions of other national groups" (Mack, p. 55). Mack was able to see how self-esteem was closely associated with the fate of the nation, especially within the military. A sense of belonging, security for survival, and self worth within the national collective is important to the nationalist.

Michael Ignatieff (2000) touches on the importance of the human need to belong within the nationalist mentality. If, he says, nationalism can appeal to a 'just' cause for war, it must appeal to people's good nature as well. Good nature is found within the family and home. Killing must be for a strong enough cause that allows a person to justify risking destroying the family and home for the sake of also protecting family and home through such horrific actions. Ignatieff notes that nationalists are sentimental "and what is better than their love of home?" (p. 9). Nationalist sentiment is important to explore within the context of the Cyprus conflict because so much violence existed in the name of the nation. It also informs present day negotiations and reconciliation efforts. Nationalists still very much exist in Cyprus and it is to that group many Cypriots say political leaders are attentive because they make up a large part of their support base.

In the case of the 1996 buffer-zone incident, two modern nationalist sentiments were combined with two older nationalist sentiments. After 1974, the Greek coup and the Turkish military occupation created nationalists that on the Greek-Cypriot side wanted the island reunited to its sovereign and territorial origin, or an ethnically partitioned island as on the Turkish-Cypriot side. Both sides focused on "their 
respective mono-ethnic and exclusivist notions of statehood" (Broome et al, 2012, p. 14), which remains a source of tension within current negotiations. The buffer-zone incident in 1996 roused that same sentiment while reinforcing the idea of the 'other' and their respective territory. Both functioned under an ethnocentric nationalist perspective based on their mono-ethnic method of statehood. According to Broome et al (2012), nationalists in the north acted on the "presumed 'right' of opposing any non-Turk from entering their space, even to the point of killing any Greek Cypriot who crossed the buffer zone" (p. 15) that stemmed from Turkish-Cypriot suffering in the 1960s combined with the conceptual image of Greek Cypriot enemies. The motorcyclists saw themselves as "asserting their patriotism, loyalty to their ethnic community, and the right to restore the integrity of their presumed Hellenic island state" combined with the view that the action of the Turks affirmed "the terrible enemy image" (p. 15). Both sides seemed to mirror their enemy images of each other in pursuit of their somewhat common agendas. This complex nature of nationalism not only structured the state of Cyprus as it is today, but has since perpetuated and informed conflicts that currently exist.

\section{Conclusion}

Having examined the literature on diplomacy and on civil society initiatives, it seems as though the most beneficial construct of reconciliation and peacebuilding on both levels requires a degree of collaboration when reaching a mutual goal. However, studies that examine the relationship between diplomacy and civil society are few and far between in Cyprus. Furthermore, the challenges experienced in Cyprus according to this literature are reflected in the form of nationalistic mentality, distrust of the other, 
and little political structural change. The literature reviewed provides insight to how life actually is in Cyprus through broader terms and understandings of nationalism and peacebuilding. Nationalism is common in Cyprus and is rooted in enosis and taksim. Each community has a citizen base still focused on having closer ties to their mother countries, which ultimately drives policies on the Track I level and impacts the work of Track II. Nationalism is a characteristic that both Tracks have in common, at least in its overall impact in Cyprus. Practical applications of such definitions and/or theories have yet to be fully applied to the Cyprus problem today. 


\section{CHAPTER III: METHODOLOGY}

The literature associated with Multi-track diplomacy and civil society engagement explores strengths and challenges related to trust building, development of bi-communal peacebuilding groups, and diplomatic involvement. There is limited research exploration of the influence and relationship between civil society and diplomacy in Cyprus and this issue has yet to be fully examined. Anastasiou (2008) addresses nationalism and its impact on the peace process in Cyprus as well as the ways in which civil society has attempted to engage with political leaders. Wolleh (2001) examined the workings of the Conflict Resolution Trainers Group and their dialogue facilitations held in the buffer zone. Diamond and McDonald (1996) consider the different avenues diplomacy can take according to diplomatic tracks available. While the different tracks of diplomacy are separate from each other, tracks may intertwine with one another depending on the needs of a nation, state, citizen base, and many other variables. In order to understand the peacebuilding environment and elements of ongoing diplomatic negotiations in Cyprus, the following question is still unanswered:

How do Track I and Track II relate to each other in reconciliation and peacebuilding efforts during ongoing negotiations in Cyprus?

Qualitative methodology was used to explore this question. This methodology was used in order to find out what was going on in Cyprus on a social and diplomatic level instead of conducting an experiment to test a theory since really none exists. Literature data was the beginning step of this process. By accumulating research conducted by Cypriot Non-governmental Organizations (NGOs), peer reviewed articles 
on the Cyprus issue, information from UN Reports, and daily Cypriot news stories, a foundation of basic knowledge was gathered in order to build a broader understanding of information available and the themes and trends already identified. Immersing in the Cypriot culture first-hand by living and working in Nicosia, the capital of Cyprus, for six months, provided an observer's insight into Cypriot culture. Finally, semi-structured interviews were conducted with Cypriots across the divide in both CSO and Public/Political sectors. This provided valuable insights into the sentiments, processes and relationships surrounding the Cyprus problem between civil society and political leaders in the past 40 years.

According to Ambert, Adler and Detzner (1995), qualitative research is intended to obtain a deeper extent of intimate information about groups of people, learning why and how people behave and think they way they do, rather than what people actually do or what they may believe on a larger scale. Qualitative research also focuses on more structural and process-based issues. Furthermore, validity of conceptualization in qualitative analysis is developed by refining theories through reshaping conceptual images of observations according to ongoing observations. Research includes analysis of texts and field observations as well as theoretical perspectives, such as those found in interviews. The qualitative methodology found within this paper adheres to the same formula; textual data, field observations, and interviews.

\section{Strategies of Enquiry}

Document Analysis. Texts to analyze were chosen based on their relevance of subject matter. If a peer reviewed article explored the Cyprus conflict to any extent, I 
read it and took notes on my computer of new information, theories, or insights. I went online every week to read news stories from Cyprus to keep abreast of any new political movement regarding negotiations and to see whether bi-communal activities were mentioned. During 2009-2010 there were a lot of articles in the Cyprus Mail regarding negotiations but did not discover any articles relaying bi-communal activities. In order to gain an understanding of official UN work, I read Reports and Summaries easily accessed on the UN website. I was able to find a few studies on Cypriot civil society while researching peer-reviewed articles, giving me a quantitative evaluation of political attitudes and categorizations. All of these texts combined laid the groundwork for further understanding the environment before living in Cyprus.

Observation. Observing Cypriot culture first hand was a fundamental part of the methodology for this research. While in Cyprus, I was immersed in the culture through my work placement, friends I made, and roommates I lived with. I was able to observe Cypriot culture in various capacities. I lived and worked in the south, but I crossed into the north daily to visit friends. The majority of my observations came from conversations at work, with friends, at cafes, events, and walking around in both communities talking to store owners. I wrote a lot of observations down in a notebook, but for the most part, I took mental notes on what I noticed. Every week I could hear car horns honking as strings of football (soccer) fans drove to and from games. Football has a huge place in Cyprus, and a lot of fans choose teams based on political backing. In general, the football team APOEL is a highly politicized team with a nationalistic fan base while Omonia consists of more politically liberal fans. Being introduced to this 
notion through a Cypriot friend was significant because it helped put the extent of politicization in the south of Cyprus into perspective. Cypriot culture in general tends to be very laid-back, especially in the summer due to the heat.

I experienced with two different Greek-Cypriots, their first crossings into the north. This was a significant event and I noted how uncomfortable they looked and how out of place they said they felt. For both Greek Cypriots, it was almost as if they were betraying their families by going through the checkpoint and both said they would not tell their parents that they had crossed. This is a rather typical reaction for Greek Cypriots in this situation. The Turkish Cypriots I knew, however, crossed several times a week into the south for various reasons; shopping, work, or to meet friends. These observations helped form a broader base of understanding attitudes and daily life in Cyprus.

Interviews. Interviews were conducted in Cyprus during the six months of my residency. Because Cyprus is a small island, it is easy to get to know the majority of Cypriots either directly or through people who know other people. Due to the small population, regardless of its ethnic and physical divide, I was able to network fairly easily and become connected to Cypriots who would be willing to be interviewed. Therefore, I used a combination of snowball and purposive sampling to recruit interviewees. Because I worked at a CSO, I was able to connect with other employees in different CSOs in both communities. I was connected with possible interviewees in the Public/Political sector through CSO employees who knew employees within the Public/Political sector across the divide. Through networking, I was able to interview 
past leaders, current CSO employees, and current Public/Political Sector employees. Despite warnings that I might experience problems recruiting people due to a kind of research fatigue on the island, I did not encounter problems. Perhaps this was because I came to know everybody I interviewed. I chose interviewees based on the sector in which they worked and their willingness to be interviewed. I sent out emails to connect with some people while others were connected through mutual friends. All of the interviewees had worked in their respective sectors for years and were passionate about their work.

I interviewed 11 people working in the public/private sector (Track I) and in CSOs (Track II) before leaving Cyprus in August 2011. Each interviewee signed a consent form that stated his or her anonymity would be protected and all data would be locked away for the duration of this research and discarded a year after its completion. Some interviews were as short as eight minutes and as long as forty-five minutes. The interview questions can be found in Appendix A and B.

Interviewees were promised anonymity, so this section uses pseudonyms in order to adhere to that agreement and protect each interviewee's identity. Please note that quotes from interviews are written verbatim. There were four male Turkish Cypriots in the Track I sector, one male and one female Turkish Cypriot in the Track II sector, one female Greek Cypriot in the Track I sector, and three male Greek Cypriots and one female in the Track II sector. The following, Table 1, includes names divided into sectors and Cypriot community as a guide: 


\begin{tabular}{|l|l|l|}
\hline Sector/Community & \multicolumn{1}{|c|}{ Turkish Cypriot } & \multicolumn{1}{|c|}{ Greek Cypriot } \\
\hline Track I & Musa & Nedat \\
Erkan & Mehmet & \\
& Nur & \\
\hline Track II & Seref & $\begin{array}{l}\text { Philomena } \\
\text { Alexandros } \\
\text { Andreas } \\
\text { Costas }\end{array}$ \\
\hline
\end{tabular}

\section{Table 1: Interviewee Pseudonyms}

\section{The Process of Analysis}

After each interview, I transcribed answers verbatim with the help of a recording device used during interviews. I applied thematic analysis throughout the entire process. Every interview was examined and analyzed individually. Finally, I compared interviews to each other with regard to answers to each question, identifying themes that may have illuminated my thesis question. It is the aim of the thematic analysis process to find repetition among interviewees' answers that eventually speak as one voice or arise with a prominent theme (Creswell, 2009).

Interview questions for each Track were the same with the exception of one, based upon the type of sector in which the interviewee. Question number 7 asked the public/political sector interviewees, "What barriers do you think political leaders face when it comes to negotiating a settlement?" Coding of interviews was completed in an anonymous manner, for the protection of the interviewees. For example, interview transcripts were identified by a code which included $\mathrm{G}$ for Greek-speaking and $\mathrm{T}$ for Turkish-speaking, which sector each interviewee worked in; "CSO" for Civil Society Organization or "PS" for Public/Political Sector, and the number of the interview. The 
end result looked something like this: "GCSO1" or "TPS3," etc. As research and thematic analysis continued themes emerged.

I printed out each interview on different colored paper in order to distinguish them. I then organized them by questions, i.e., I excerpted each answer and placed it with answers to the same questions onto a huge easel pad. I was then able to discern patterns within the answers; themes which emerged, similarities and differences across communities and Tracks. Each page was marked by the end of this process with analysis notes, specifying interesting elements in this thematic analysis. Categories and themes had emerged at this point, all of which are described in detail within the Discussion of Findings chapter below.

It is important to note that answers from each interviewee had their culture and gender taken into consideration during the process of analysis. This ethnographic approach helped bring more cultural perspective to each answer and to the themes that arose during this process. As it turned out, gender did not seem to make a perceptible difference to answers.

Comparing and contrasting multiple voices in corresponding sectors answering one question allowed themes to emerge. By grouping answers according to question, it was easier to see key words that were repeated from interview to interview. By coding each interview at least three ways, patterns across the divide, sectors, and sometimes gender and language, helped to differentiate one from another and suggest underlying relationships and common concerns. 


\section{CHAPTER IV: DISCUSSION OF FINDINGS}

Interview questions, textual analysis, and observations provided data with which I could explore the overall question of this paper; how do Track I and Track II relate to each other in reconciliation and peacebuilding efforts during ongoing negotiations in Cyprus? Interviews conducted were the most important aspect in illuminating findings to this question. However, the literature analysis and the observations contextualized and echoed the importance of themes which emerged in the interviews. Through the analysis of interviews, three major themes emerged. These themes speak to the barriers to cooperation between Track I and Track II Diplomacy, which are in the nature of both

political and structural challenges. These themes are: Structural Elements, Nationalism, and International Influence. I have organized my findings within these themes according to answers from Track I and Track II sectors of interviews.

\section{Track I Themes}

Interviewees from both communities within the public/political sector indicated that the level of politicization in both communities hinders long-term peacebuilding work as well as obstructing a political solution. Interviewees from both sectors and communities spoke to the high level of politics that exist in the south that has affected civil society and diplomacy. Nationalistic mentalities are supported by such politicization, further hindering any cooperative peacebuilding efforts. Influences from mother countries, from countries with strategic interests in the island, and lack of international support for peacebuilding and reconciliation have created barriers to cooperation between tracks. 
Structural Elements. The lack of cooperation between Track I and Track II is contingent upon the following factors: political barriers, monetary support, historical legacy, civil society involvement, and mutual support. The interview questions that evoked these themes were numbers 3 through 7. A barrier to CSO work, according to Track I interviewees, is based on their lack of funding. Sedat said that while "most of the activities are supported by other organizations or governments" the support is not enough and the lack of volunteers within CSOs and high competition for grants make it so "it's about funding." Funding is low and therefore visibility is low, events are sparse, attendance is low, and organizations are understaffed. Sedat went on to mention that "unfortunately the businessmen are not that much into bicommunal activities in order to destroy the walls" because it would greatly increase civil society involvement as well as obtain funding through business-based endorsements. Along those same lines, civil society awareness can help gain societal involvement. Mehmet said that "to increase awareness of civil society in Cyprus, they have to become more effective and they must also come up with better projects supporting reconciliation activities and other events and activities which will help the two societies come together." Furthermore, Sedat suggested that "social integration is a must for a political solution because it is much more acceptable to integrate the communities or people and let them live together and the efforts by Track I is not enough alone to maintain a sustainable solution," which to several interviewees, is an important aspect of the reconciliation and settlement issue.

It is important to note that the original, although abstract, question of this paper asked 'which comes first, the chicken or the egg?' This begs the question, who leads the 
reconciliation efforts, political leaders or civil society? Sedat notes that it is important how leaders "behave, how they look, and what is their expectation because it directly effects the behavior of the community" because "the political leaders played a great role on peacebuilding. But this is a question a bit like the egg and the chicken, because you know the people are choosing the leaders." He goes on to say that "that's why it is also important what the people are thinking because they can play a constructive role and this is very important" for leaders to remember since "they are in front of the media and they have got the power to talk." In short, the lack of mutual support between Track I and Track II hinders the peace process because each Track does in fact influence the other to some degree. Mutual support and even the issue of inclusiveness between the two sectors is important because, as Erkan said, "every time the government makes a decision, they do it with out consulting civil society and then in return you see people having protests and uttering very critical slogans," which further hinders any cooperation between the two sectors. While the relationship between both sectors is important, Musa brought up the importance of a good relationship between the two leaders and society's role. He says, "the system is locked in such a way that without the consent of the leaders a solution will not be possible, even if civil society organizations concur on issues the solution will be fully dependent on the decision of the leaders. They have to help the leaders find a way to change their minds, change their policies. Their concentration should switch from, I mean, working for the betterment of the climate of two societies to the betterment of the relationships of the two leaders." So while political leaders have the power and voice when it comes to negotiating a 
settlement, Musa is saying that civil society could help with this effort by supporting a positive relationship between leaders. Nicolina reiterated this need for support, "politicians pay lip service to the need for dialogue with the other but do not follow through in practice and there is no demand from the society for a process of reconciliation to start." On top of that, Nicolina says, "peacebuilding and reconciliation efforts have never been part of the agenda of the political elite on either side. The attitude has been, we need a solution first, reconciliation comes later. So there has been no support for civil society efforts even at times when negotiations for a solution are being carried on, as at the present time." This seems to point to a complete gap between the two sectors, each one informing the other with their action, or lack of action. Based on interview answers, it seems as though there is a vicious cycle, where, because political leaders have never fully supported reconciliation through negotiations, civil society has not fully supported negotiation efforts due to the lack of reconciliation.

Another barrier within this theme has to do with the failure of the Annan Plan. The Annan Plan had both political and societal reconciliation aspects. It was to be the final settlement option and reconcile the two communities once and for all. When the Greek Cypriots voted against it, it created more of a division and more animosity between the communities. Erkan suggested "the unification failed because you didn't have many people being aware of the Annan Plan.” This is because usually civil society organizations "bring the bottom up approach and that's why you can have more acceptance from the wider public...in Cyprus usually things take place from up to bottom so the leaders decide and the people have to either accept it or revolt against it," 
creating dissonance between the two sectors. Instead of having only animosities carried from the 1974 war, Erkan says now "we have the blame game."

Nationalism. Nationalism in Cyprus is and has been prevalent for years. Nationalists make up a large constituency base and therefore impact the speech, decisions, and behavior of leaders. Nationalism arose as a theme within two questions. When asked question 7, "What barriers do you think political leaders face when it comes to negotiating a settlement?" several interviewees across the divide suggested that political supporters and historic political roles have been formed by nationalists as barriers in both societies. Nationalists make up a large support base for political leaders. As Mehmet said, "they [political leaders] have populace barriers because in order to win the elections they have to make the nationalists happy and this is a huge barrier for government." The influence of nationalists not only influences local politics, it also influences the way both leaders approach negotiations. Erkan speaks to this issue as well, "at the moment our president has the support of the government but he is in conflict with his support base which is mainly the nationalists so he has to be very careful in proposing something" regarding negotiating a settlement. Sedat further supported this theme when he said that leaders, regarding nationalist supporters, "have to be careful about what the supporters are saying, that's why there are too many dimensions on the issue. They have to be careful." Musa saw a major barrier for political leaders being the "established entrenched formal official positions" that "they are enslaved by," which are mostly founded within nationalistic mentality and historical rhetoric. 
International Influence. This theme arose throughout questions 5 through 7. Support from the mother countries, Greece and Turkey, play a large part in political decisions and the extent of political independence each leader has when it comes to negotiating a settlement. According to the interviewees, the lack of political independence has a major role in the lack of negotiation abilities. For example, Erkan said that, "for our leader, he has to consult everything with Turkey, the policies have to match each other. He can't be $100 \%$ independent. He has to take into consideration of Turkey's role, Turkey’s relations with the EU, and Turkey's relations with other countries. So he cannot either say I'm pulling out or I can everything in one day...he has to first negotiate with Turkey and then with Christofias. That's the biggest barrier for our leader." Because of political support and ties to surrounding countries, Sedat says, "the relationship between foreign countries is an issue" so leaders "have to be careful about finding a balance on the solution to the Cyprus problem" in order to maintain their international support. For Turkish Cypriot leaders, the Cyprus problem impacts Turkey's accession into the EU to some extent, so there is a feeling of obligation to keep moving forward with negotiations. Because Greek Cypriots are already members of the EU, there is less of a pull to negotiate although President Christofias has been negotiating a settlement more than any other President in the past. To the same degree, however, both leaders are still not able to act as independent leaders due to ties to the mother countries.

Findings indicate that Track I experiences structural challenges as well as influence from nationalists. Many decisions are reliant upon the influence and 
permission from mother countries, especially in the north, where there is a direct link to Turkey politically and economically. The nationalistic constituent base and support from mother countries seem to directly influence structural elements of peacebuilding, reconciliation, and settlement negotiations.

\section{Track II Themes}

Themes arising from Track II interviews were similar in that the themes of structure, nationalism, and international influence impacted peacebuilding and reconciliation work. However, due to the nature of CSOs in Cyprus, nationalism and international support or influence were felt less than the lack of structural elements. Findings demonstrated that the level to which Track II felt the impact of each theme was because of the lack of structural support. Credibility and support from Track I to Track II was lacking, the level of politicization in Cyprus influenced CSO work, historical mental barriers, funding, and societal awareness and involvement were all very relevant themes speaking to the lack of cooperation between Tracks.

Structural Elements. Many barriers to peacebuilding efforts that exist within the CSO realm are similar to the challenges that Track I experiences. Credibility and support for CSOs is highly lacking, as Nur points out when asked question 5, "What barriers do you think civil society faces in relation to peacebuilding and reconciliation efforts?" Her answer was that "the government isn't giving any credibility to what civil society is doing so no support goes to civil society organizations and therefore, what civil society organizations are doing looks like a couple of hippie people getting together celebrating peace and love and nature." More than that, the lack of structure 
within CSOs themselves gives these peacebuilding events a bad name. Nur says that while the CSOs have a lot of good will, "they have never been structured enough, so it has always ended up just a couple of days of fun and never went anywhere," however, she adds, "this is not only civil society's fault, it's not only about them. It's not that they could not do it, there's more to it" than having all responsibilities rest on the shoulders of the CSOs. It comes down to support, credibility, funding, and awareness.

The lack of credibility and support for CSOs affects multiple aspects of peacebuilding efforts. Funding is a major problem and along with a lack of funding comes the structural issue of sustainability in peace work. Philomena said "one big barrier is lack of media attention by, especially in the Greek Cypriot community, by media, promoting positive work that's taking place. Other problems is lack of funding opportunities and obviously the mental barriers that still exist very much to a great extent. We also have that with the parents of the children and that is something that it needs, is long term efforts and the majority of civil society work, because it's based on short term projects, is not able to produce long term results for the future." Sustainable peace work is something that would benefit civil society, allowing citizens to support their leaders in negotiations. Without "sufficient funding," Costas says, "and the right people, then, many, many things can't be done." While there have been successful events given the extent of the resources "and the lack of political will to support them, they are definitely not the mainstreams," Philomena says, "they haven't taken off to the broader public and they have been based primarily out of Nicosia" which doesn't allow Cypriots in other areas to get involved. She adds, "not that civil society work in Cyprus 
overall has such a strong role." Findings have indicated that within Track II perspectives, the lack of Track II work, support, funding, and awareness have impacted the way peacebuilding and reconciliation have been structured. This has influenced contributions CSOs are able to make in society and in policies. Since the concept of civil society is fairly new to Cypriots, its role is not clear nor has it been able to become widespread.

When asked question 7 "In what ways do you see CSOs contributing to policies, local politics and peacebuilding in Cyprus?" Costas reply was simply, "minimal.” This is due to the lack of credibility and support, leaving little power to CSOs to make a difference and, Costas goes on to say, "if they are effective it will be purely by accident, by coincidence. There is, there are many ways to change things but who is going to do that? So we are trapped." Seref further supported this attitude when he said there is "a structural problem also environmental problem. People, they don't have the civil society culture they have a state culture...I think this is an important problem and they don't discuss this because they always say how are we going to improve the NGO but there's a big cultural problem and no one talks about that." Without a civil society culture, or movement, as Costas pointed out, no one is left to do the work from the bottom up.

The relationship between Track I and II according to those in CSOs is little to none. Nur says that "there is no relationship between both, unfortunately. Even if it looks even if they're trying to show there is, I don't believe there is. They're very far away from each other and they're very extremely different." Philomena pointed to the UNDP-ACT program and its efforts in cooperation and trust, having "tried to link the 
civil society process to the Track I efforts but the Track I diplomacy is not very open to this type of involvement so far, at least it hasn't shown that [it is]." The reason behind this, Philomena goes on to say is, perhaps " because civil society in Cyprus is not viewed yet as something very solid and not personal interest driven, it's hard for political leaders to open up a mode of communication with civil society whereas they do that regularly with political parties." To Costas, however, the relationship is a bit different, although still lacking, because "the political parties in Cyprus have their own youth like segments of the party...they present themselves as if they're part of civil society so they take over a role, which would otherwise be in the hands of people who are outside of political parties. A great many of the so-called peace initiatives have been organized by the youth of political parties. It's as if they are extensions of parties themselves so this means that we a have gray area. It is not easy to talk about Track I and Track II if we have Track I and a half. And if Track I and a half belongs to Track I." This demonstrates the level of politicization in Cyprus, which ultimately affects even the perception of what civil society is and does. According to Seref, "Track I has influence on Track II and III, because this is maybe everywhere, but here what politicians say really matters. For example, if there a positive rhetoric, that has a huge influence on what you can do and everything and it the Track I people allow civil society to engage in this thing, I think it might have an influence as well. Right now, they don't do much...I don't think the Cyprus problem can be solved with Track I, it is impossible." Although there is a high level of politicization in Cyprus, "people are more open to and trust events by CSOs than to politicians actually, because especially in our 
island, people have lost trust to politicians, they have lost their credibility, so it will be difficult for people to trust politicians again," Alexandros said. This makes it difficult to become involved in politics and due to the lack of credibility and support for CSOs, makes it difficult to become involved in peacebuilding work. What Cypriots do, especially in the south, is to step away from both sectors and not involve themselves in either side. This has created an apathetic environment where Cypriots go through their days as they would in any non-post-conflicted country.

On the other side of the extreme, however, are Cypriots that get incredibly involved on a political level in a nationalistic way but steer clear of any CSO work being done. Part of this has to do with the historical aspect of the conflict. Another part has to do with, as Costas said, "that Cyprus is a very small island and a lot of people know when you do something. So a lot of people are reluctant to enter civil society groups and to be active in ways that would be high profile. Many people prefer to work as low profile as possible. This means that they are not as effective as they would like." The reason this is important, Costas said, is because "people are branded." Meaning, the consequence is political since "on the Greek Cypriot side the parties have a great deal of control" and "it reaches great levels of every day life. For example, if you are, if you become undesirable to one party, you might never get a job. Or you might never get promoted," which is yet another example of the high level of politicization. Another barrier Costas sees in CSO work is that "there is a great deal of ignorance of the history of the island" about what really happened and why it may have happened. Basically, people do not have an understanding about what really happened and have stories from 
their parents or from school about the conflict, both of which tend to be very one-sided. Education in Cyprus, according to Costas, "is specifically designed to prevent young people to think for themselves. They find little meaning in life, they have few aspirations. Their aims are directed towards money and wealth and so on...so this means they have very little interest and very little help in order to become involved in civil society." Since there are other interests for those in power, political leaders, church leaders and those with financial interests in Cyprus, "are doing what they can to keep it in a very embryonic stage," namely, not supporting or giving credibility to CSO work.

Nationalism. All questions asked rarely brought up the theme of nationalism for those working in Track II and did not appear as relevant as it did to the Track I interviewees. Most nationalistic issues were noted as being mental barriers from memories of trauma from the war instead of pointing to nationalists in general. This is exemplified by Alexandros when he mentioned that "a big barrier is the narrowmindedness of the old people...the past generation that actually lived the war" and it is that generation that is hard to reach out to on a reconciliation level. Costas, however, said that, whether it is from church leaders or grassroots leaders, "we had a lot of influence from those individuals who were nationalists and encouraged specific ways of thinking and specific ways of action for the pursuit of the union with Greece," making it a challenge to move forward with reconciliation efforts.

The issue of nationalism, while applicable to Track I because of their support base, is rarely brought up as important within CSOs. Barriers within this theme have to do with the mentality of civil society, whether that actually comes down to the 
nationalism that exists, generational influence, historical impact, or familial loyalty. Being loyal to the family is culturally significant and if parents or grandparents taught their young from a small age that the other side created his or her trauma, this produces demonization. This demonization could stem from a nationalistic mentality since union with Greece or Turkey was and still remains an important issue.

International Influence. Question 3 through 8 evoked some themes having to do with international support or influence within Track II. International influence, specifically, is something that Cypriots are aware of to some extent. The impact of what political leaders in other countries have in Cyprus has an affect on Cypriot political strategies when it comes to reconciliation and negotiations. Philomena exemplified this when she spoke of the role of political leaders and barriers they may face, "the blame game is not something that's helping them in the negotiation process. Also nonsupportive statements by some countries is not helping them, like Egypt and Turkey." According to Alexandros, international influence has a lot to do with the ongoing conflict in Cyprus; "the big countries, United States of America, Great Britain, have strategic interests in our island. I have read that they used to place people on our island to incite the conflict between the communities because keeping the people divided, it makes it more easier for others to come to the island and impose their views and actually introduce as a way of solution," and it is "a result we can see. It's not mythological or something, it's something you can see that is happening right now." 


\section{Overall Findings}

According to interviewees from both Tracks, structural elements, nationalism, and international support influence aspects of peacebuilding, reconciliation, and negotiations. While all Tracks have these themes in common, it is Track I that felt more influence from nationalism and international support than Track II. Track II felt more influence from structural elements than the other two themes. Findings suggest that because CSOs rely on structural support more than political constituency and on the support of other countries, politically, it would make sense that they feel more of an impact when it comes down to structural elements such as funding, credibility, and mutual support from Track I. Because Track I is so strong in Cyprus, it is understandable that their structural elements have less to do with negotiations and more to do with the relationship with Track II. It is also understandable that Track I would feel more of an impact when it comes to nationalistic influence and international support, since Track I makes up a lot of the structure in Cyprus while nationalists and other countries have more power over Track I decisions and actions. Overall, findings indicate that while there are degrees to the extent of influence according to Track I and II, the themes of structure, nationalism, and international sway impacts reconciliation and peacebuilding efforts as well as in negotiating a settlement for the Cyprus problem.

In conclusion, when we look at Track II and Track I, it is the barriers that are their only relationship. These barriers, as summarized in Table 2 are; a lack of mutual support between the tracks, a lack of credibility and support from Track I for Track II, a 
lack of funding, political barriers, failure of the Annan Plan, and historical mental barriers.

\begin{tabular}{|l|l|}
\hline \multicolumn{1}{|c|}{ Track I } & \multicolumn{1}{c|}{ Track II } \\
\hline $\begin{array}{l}\text { A lack of mutual support between the } \\
\text { Tracks }\end{array}$ & $\begin{array}{l}\text { Credibility and support from Track I is } \\
\text { lacking }\end{array}$ \\
\hline CSOs lack funding & $\begin{array}{l}\text { Funding is lacking, meaning work is not } \\
\text { sustainable and awareness is low. }\end{array}$ \\
\hline $\begin{array}{l}\text { Peace efforts have never been a part of the } \\
\text { agenda }\end{array}$ & High politicization \\
\hline Failure of the Annan Plan & Historical mental barriers \\
\hline Overall political barriers & \\
\hline
\end{tabular}

Table 2: Comparison of Structural Elements

The second type of barrier is nationalism, as summarized in Table 3. This included; a strong nationalistic constituency, influence from nationalists on political agendas, nationalistic mentality which blocks outreach, the desire to stay low profile to due the small size of Cyprus, and nationalists' strong ties to mother countries.

\begin{tabular}{|l|l|}
\hline \multicolumn{1}{|c|}{ Track I } & \multicolumn{1}{c|}{ Track II } \\
\hline Strong nationalistic constituency & $\begin{array}{l}\text { Nationalistic mentality blocks outreach in } \\
\text { civil society }\end{array}$ \\
\hline $\begin{array}{l}\text { Influence from nationalist on political } \\
\text { agenda }\end{array}$ & $\begin{array}{l}\text { Small island, many prefer to stay low- } \\
\text { profile }\end{array}$ \\
\hline & $\begin{array}{l}\text { Strong ties to mother countries, Turkey } \\
\text { and Greece }\end{array}$ \\
\hline
\end{tabular}

\section{Table 3: Comparison of Nationalism}

The third barrier is international influence, as summarized in Table 4. This includes influence from mother countries, relationships with the EU, lack of political 
independence, the blame game from other countries, and strategic interests in Cyprus from other countries.

\begin{tabular}{|l|l|}
\hline \multicolumn{1}{|c|}{ Track I } & \multicolumn{1}{c|}{ Track II } \\
\hline $\begin{array}{l}\text { Political influence from mother counties, } \\
\text { Turkey and Greece. }\end{array}$ & $\begin{array}{l}\text { Blame game from other countries such as } \\
\text { Egypt and Turkey }\end{array}$ \\
\hline Relationships with the EU & Strategic Interests in island from others \\
\hline Lack of Political Independence & \\
\hline
\end{tabular}

Table 4: Comparison of International Influence 


\section{CHAPTER V: IMPLICATIONS, RECOMMENDATIONS, LIMITATIONS AND CONCLUSION}

Central themes established here was that the relationship between Track II and Track I held an array of ongoing challenges. These challenges were similar in both sectors but the reasons for the challenges somewhat differed from each other as did the emphasis. The theory that arose most predominantely was that the relationship between Track I and Track II is kept very much separated by the country's political atmosphere, which does not support awareness or education relating to reconciliation and peacebuilding with the majority citizen base.

\section{Implications}

The lack of funding, societal awareness, outreach, and high politicization that Track II experiences, is a result of a lack of structural support from Track I. The mental and historical barriers that citizens have towards reconciliation on the societal level are also the result of lacking structural support. The history of the conflict has been modified in schoolbooks on both sides of the divide, framed by nationalist rhetoric to tell one story. The historical framework provided in textbooks has made it so that support for reconciliation and peacebuilding is deterred from a young age. The majority of Cypriots has never crossed the buffer zone, has never been fully educated on the conflict, and lacks the desire to come together and reconcile.

A possible reason that many say there is no relationship between Track I and Track II is because civil society is a new concept and the state and politics are indeed one and the same in Cyprus. When a new concept like civil society arises in a highly 
politicized post-conflicted state, it makes sense that civil society would be seen as completely detached from the state itself. A sense of empowerment on the societal level is deficient in Cyprus based on responses. While there are many CSOs in Cyprus, the amount of nationalists and lack of political support seems to outweigh their efforts. The ways in which peacebuilding activities and events are structured also inform the environment of reconciliation. There were many ideas as to how peacebuilding capacities could be enhanced, but no reasons why each event or activity is not currently structured in such ways.

A re-occurring question and something that was mentioned frequently, was the economic oppression in the north. I found that a few Turkish-speaking Cypriots were open and willing to work towards a solution on the societal level and wanted a resolution on the diplomatic level. Many bluntly stated that those in the north were more willing to work for peace than those in the south because of their problematic economic and international status. A few interviewees echoed my own observations in casual conversations when they mentioned that those in the south were comfortable with the status quo and that were anything to change, jobs would not be secure and the economy would change, making reconciliation in the south more of a challenge. I deduced that the lack of localized and focused peacebuilding work in the south was not solely because of high politicization, but because life in the south is much better economically, politically, and socially, than in the north. This meant that Greek Cypriots were not as motivated to make a change in their status quo. While both communities share common interests, retail tastes, and a similar way of life, the 
economic status in the north is less than that in the south. A majority of Cypriots in the south live a comfortable life and receive benefits from being a member of the EU. This

means that CSOs in the south have more access to grants, which means more money for funding, albeit short term. Although many CSOs choose to work together across the divide, money allocated is for very specific purposes. Since there never seem to be enough resources to go around, not a lot of money is obtained versus utilized. This means that any event is short term, low budget, and requires a lot of manpower. Because civil society involvement is so low, those that are involved work to put together these peacebuilding events while also working a full time job.

\section{Limitations}

Limitations in the research had to do with participant willingness, language barriers, and culture. Mediterranean culture is fairly casual and unstructured in comparison to American pace of everyday life. While in Cyprus, I learned that when I make plans at 8pm, I know that the other party may not show up until half past or even an hour later, and this is acceptable. I also learned that in order to get something done when it relies on someone else, it is important to always touch base and keep on top of its status. It was also necessary to constantly be translating from my American English to British English as a second language, since that is the English Cypriots learn. Limitations regarding interview questions relied on the Cypriot way of communicating answers. Cypriots tend to view questions as guidelines for their answers rather than direct questions supposing direct answers. The number of participants in the study was determined the availability of willing persons as well as the number of times I was able 
to touch base to set up concrete meeting times. Translating interviews verbatim was a challenge because of the language barrier. My personal experience and observations in Cyprus were vital to this research and at times it was a challenge to remain neutral.

\section{Recommendations}

Contributions from every interviewee embodied recommendations or ideas. This shows that while participation in peacebuilding activities may not be in abundance, many in each sector has an idea of how it should or could be improved. Between Track II and Track I, an important reoccurring statement about reconciliation and peacebuilding activities was to create a more sustainable and productive environment instead of short term "entertainment" or get-togethers. Furthermore, a heightened support system from leaders could not only raise awareness about peacebuilding activities, but also elevate the sense of togetherness and community across the divide. Accordingly, Track II could make efforts to support and encourage a healthy relationship of both leaders as well as supporting settlement negotiations.

Findings indicate that peacebuilding capacity in Cyprus is lacking. Views on what strategies should be adopted and pursued in order to increase peacebuilding efforts had to do with increasing awareness, relationships, cooperation, and involvement within civil society in both communities. Each interviewee from both Tracks had suggestions on how new strategies for peace could be adopted and on how the relationship between both Tracks could be structured in order to enhance peaceduilding capacities overall. Ideas on how to do this were, but not limited to, the following:

- More sustainable events instead short-term events. 
- Create more of a partnership with the media in order to be more visible and vocal in outreach.

- Activities should be more productive than entertaining, helping societies come together.

- Events should be more balanced in participating members, objectives, and locations.

- Bring in international organizations to help create a strong model of CSOs and peacebuilding work.

- Build libraries in every major town on the island.

- Have people work side by side in business, not just events.

- Gather rejectionists (re: Annan Plan) and nationalists from both sides and take them to a secluded area for a few days for reconciliation activities.

- Organize events like cheese and wine parties in a neutral area without listing the guests or sponsorship.

When asked for suggestions on how both Tracks should be structured in order to enhance peacebuilding, several different ideas emerged. For Track II, it was important that civil society be more informed about negotiations and become more involved and heard by leaders. For those in Track I, preparing the people for a settlement was important. The following list exemplifies if not specific ideas, overarching desires during the course of negotiations and reconciliation:

- Create a civil society advisory council to the leaders.

- Publicize when leaders have social time together to show that even during difficult negotiations, they can socialize and live together.

- Institutionalize everything: labor organizations and business association involvement, on leaders' schedules. 
- Track II integrates communities socially by being a networking tool through peacebuilding efforts with Track I supporting this effort on all levels.

- Leaders should make positive statements often in order to prepare civil society for a solution and reconciliation.

- Work on changing history and other schoolbooks on both sides to be neutral.

I recommend that further research that includes interviews on both sides across an array of disciplines be conducted on a larger scale than what I was able to accomplish in my short time in Cyprus. Gathering the opinions, perspectives, and suggestions from Cypriots on which peace-enhancing initiatives could prove to be helpful in the long run is important to creating sustainable relationships between the communities. I also suggest that, as one interviewee recommended, international organizations be invited to set up shop, so to speak, and help with funding, ideas for events, networking, and grabbing media attention. This would help to alleviate the embedded politicization that inevitably reaches CSOs and their efforts. If the $\mathrm{UN}$ or EU were to become more involved this would push the guarantors (Turkey, Greece, and the UK) to speak up and become more involved in the peace process as well. Since the Cyprus issue has become an international problem, it is time for the international community to pull their weight where necessary to expedite negotiations and put pressure on Cypriots to become more involved in reconciliation and peacebuilding efforts.

Research is important as a prelude to action and at the end of the day, action means more than research. There is a never-ending amount of research that can be done on the Cyprus conflict, its citizens, and political system. However, over the 40 years of this conflict, politics, nationalism, lack of funding and focus, and international support 
has hindered any major step forward. Negotiations between leaders have come to an impasse and have been fast-tracked. I think it is important to ask why, after over 40 years of conflict, is this island still divided? While this paper may have touched on this question to some degree, there are many gaps to be filled. I observed many Cypriots focused on material aspirations as stray animals roamed the streets and buildings crumbled. I observed Cypriots in the north crossing to the south for employment or to shop as Turkish and Cypriot police became aggressive with protesters taking a stand against Turkey's overwhelming political involvement.

\section{Conclusion}

In conclusion, it is important for Cypriots to recognize how reconciliation by both sectors can and will have an effect on the course of negotiations. Before solidifying my question for this paper and research, I initially wanted to know which came first in Cyprus; the chicken or the egg? Do politics run the course of a resolution and reconciliation, or does civil society? I am now convinced that while it is up to the leaders to negotiate a diplomatic solution, it is civil society that ultimately accepts or rejects their new way of life once a resolution is reached.

Anastasiou speculated that the following, as summarized in Table 5, provides a partial explanation of why there is a rupture between Track II and Track I in each community (Personal communication, June 12, 2012). Since Track I on the GreekCypriot side promotes enosis (unification with Greece) due to its loyalty to its mother country, but Track II on the Greek-Cypriot side is content with its status quo of economic prosperity as a result of its EU enlargement, Track II actually has little 
interest in supporting re-unification. In contrast, Track I on the Turkish-Cypriot side, also due to its loyalty to Turkey seeks taksim (partition of Cyprus). However, Track II on the Turkish-Cypriot side lives at a lower standard of living than the Greek-Cypriot side, they seek more economic exchange and therefore are more interested in equal status. The result is that the Greek-Cypriot Track II may be more compatible with the Turkish-Cypriot Track I and vice versa than either Track II is with its own Track I. This means that while this island is divided in many ways, it will continue to be so until CSOs and politicians can work to support each other. It is Track I that leads this process due to the level of politicization and it is Track II that could help support leaders in negotiations and reconciliation.

\begin{tabular}{|c|l|l|}
\hline & \multicolumn{1}{|c|}{ Track I } & \multicolumn{1}{c|}{ Track II } \\
\hline Greek-Cypriot & $\begin{array}{l}\text { Seeks unity with Greece, } \\
\text { reconciliation }\end{array}$ & Content with status quo \\
\hline Turkish-Cypriot & Seeks partition of the island & $\begin{array}{l}\text { Seeks equal status, } \\
\text { reconciliation }\end{array}$ \\
\hline
\end{tabular}

Table 5: Comparison of Tracks Across the Divide

If leaders began to vocalize the legitimacy and importance of reconciliation it would help CSO visibility, funding, and influence on the peace process. In turn, CSOs could call for a better relationship between both leaders and support them in their cause with their appropriate capacities, whether that is through events, media, or direct communication. Nationalism will always exist, but the extent of nationalistic influence on Track I in Cyprus could dissipate if Track I ceases to allow nationalists to have the same power as they do now. This way, Track I could create a space where negotiating a settlement is not only necessary, but beneficial overall, and communicate that through 
civic engagement and ongoing productive negotiations. By supporting each other, Track I and Track II could begin a new relationship where, no matter what, peace is the goal. 
Diplomacy and Society in Cyprus

\section{LIST OF REFERENCES}

\section{$\underline{\text { Reference: }}$}

Ambert, A., Adler, P., Detzner, D. (1995). Understanding and Evaluating Qualitative Research. Journal of Marriage and Family, 57, 4, pp. 897-893.

Anastasiou, H. (2002). Communication Across Conflict Lines: The Case of Ethnically Divided Cyprus. Journal of Peace Research. 39, 5, pp. 581-596.

Anastasiou, H. (2008). The Broken Olive Branch (Vol. 2). Syracuse, NY: Syracuse University Press.

Anastasiou, H. (2009). Cyprus as the EU Anomaly. Global Society, 23(2), 129-151.

Anderson, B. (1995). Imagined Communities: Reflection on the Origin and Spread of Nationalism (pp.76-83). London \& New York: Verso

Annan, K. (2004). The Comprehensive Settlement of the Cyprus Problem. United Nations.

Bar-Tal, D. (2000). From Intractable Conflict through Conflict Resolution to Reconciliation: Psychological Analysis. Political Psychology, 21(2), 351-365.

Boutros-Ghali, B. (1992). An Agenda for Peace; preventive diplomacy, peacemaking and peace-keeping. http://www.un.org/Docs/SG/agpeace.html . See also Boutros-Ghali, B. (1995). Supplement to an agenda for peace: position paper of the secretary-general on the occasion of the fiftieth anniversary of the United Nations. A/50/60 - S/1995/1.

Brands, H.W. Jr. (1987). America Enters the Cyprus Triangle, 1964. Middle Eastern Studies, 23(3), 348-362.

Broome, B., Anastasiou, A., Hadjipavlou, M., Kanol, B. (2011). Opening Communication Pathways in Protracted Conflict: From Tragedy to Dialogue in Cyprus. In Frey, L. and Carragee, K. (eds.) Communication Activism. Vol. 3. Suffolk University, Boston, Massachusetts, pp. 69-104.

Creswell, J.W. (2009). Research Design ( $3^{\text {rd }}$ Edition). Thousand Oaks, CA: Sage Publications

de la Rey, C. (2000). Reconciliation in Divided Societies (pp. 251-261). Peace, Conflict and Violence: Peace Psychology for the $21^{\text {st }}$ Century: Prentice Hall. 
Diamond, L. and McDonald, J. (1996). Multi-Track Diplomacy: A Systems Approach. $3^{\text {rd }}$ edition. West Hartford, CT: Kumarian Press.

Galtung, J. (1976). Three Approaches to Peace: Peacekeeping, Peacemaking, Peacebuilding. In: Peace, War and Defense; Essays in Peace Research (Volume 2). Copenhagen: Christian Ejlers.

Gürel, A. and Özersay, K. (2006). The Politics of Property in Cyprus. International Peace Research Institute, Oslo (PRIO) Report 3/2006.

Gürkaynak, C. (2007). Track Two Diplomacy from a Track One Perspective: Comparing the Perceptions of Turkish and American Diplomats. International Negotiation, $12,57-82$.

Hobsbawm, E. (1994). "The Nation as Invented Tradition," in Hutchinson \& Smith, editors, Nationalism. Oxford: Oxford University Press.

Katrivanou, V. (2009). Intimate Interactions: The Women of Cyprus. Contextual Essay, Portland State University.

King, R. and Ladbury, S. (1982). The Cultural Reconstruction of Political Reality:

Greek and Turkish Cyprus Since 1974. Anthropological Quarterly, 55(1), 1-16.

Lederach, J.P. (2002). Building Peace: Sustainable Reconciliation in Divided Societies. Washington, D.C.: United States Institute of Peace Press.

Liang, Y. (2008, June). Cyprus Calls for Turkish Army Withdrawal. In Chinaview.cn. Retrieved November 8, 2011, from http://news.xinhuanet.com/english/200806/20/content 8403916.htm

Loizos, P. (1988). Intercommunal Killing in Cyprus. Man, New Series. 23(4), 639-653.

Mack, J. (1983). Nationalism and the Self. Psychohistory Review, Vol. 11, 47-69.

Marchetti, R. and Tocci, N. (2009). Conflict Society: Understanding the Role of Civil Society in Conflict. Global Change, Peace \& Security, 21(2), 201-217.

Michael, M. (2007). The Cyprus Peace Talks: A Critical Appraisal. Journal of Peace Research, 44(5), 587-604.

Montville, Joseph. (1987). "The Arrow and the Olive Branch: A Case for Track Two 
Diplomacy and Society in Cyprus

Diplomacy," in J. McDonald \& D. Bendahmane, editors, Conflict Resolution:

Theory and Practice. Washington, DC: Foreign Service Institute, US

Department

of State.

Orwell, G. (1945). Notes on Nationalism. In Orwell, S., and Angus, I. (eds.). Collected Essays, Journalism and Letters of George Orwell, Vol. 3. Harcourt Brace Jovanovich, Inc., New York (1968), 361-380.

Pruitt, D.G., \& Rubin, J.Z. (1986). Social Conflict: Escalation, Stalemate and Settlement.

New York: Random House

Turk, Marco A. (2006). Cyprus Reunification is Long Overdue: The Time is Right for Track II Diplomacy as the Best Approach for Successful Negotiation of this Ethnic Conflict. Loyola of Los Angeles International and Comparative Law Review. 205 (28).

United Nations (2009). UN Report 610 (S/2009/610). UN Secretary-General Ban KiMoon.

United Nations (2010). UN Report 603 (S/2010/603). UN Secretary-General Ban KiMoon.

United Nations (2010). UN Report 498 (S/2011/498). UN Secretary-General Ban KiMoon.

United Nations (2011). Historical Chronology. Retrieved November 14, 2011, from http://www.securitycouncilreport.org/site/c.glKWLeMTIsG/b.2699911/

UNFICYP (n.d.). History, Key Dates. Retrieved November 8, 2011, from http://www.unficyp.org/nqcontent.cfm?a id=1349\&tt=graphic\&lang=11

USIP (2003). Simulation on the Use of Force in Chechnya: An Exploration Through Track-Two Diplomacy. Teaching Simulation; United States Institute of Peace.

Volkan, V. (1985). The Need to Have Enemies and Allies: A Developmental Approach. Political Psychology, 6(2), 219-247.

Wolleh, O. (2001). Citizens' Rapprochement by the Local Peace Constituencies: Bi -communal Conflict Resolution Trainer Group in Cyprus (Report No. 8).

Berghof

Research Center for Constructive Conflict Management. 
Diplomacy and Society in Cyprus

Yilmaz, M.E. (2010). Capturing the Complexity of the Cyprus Conflict. Turkish Journal of Politics, 1(1). 


\section{Appendix A: Questions for those active in Civil Society Organizations (CSOs):}

1. Tell me about the kind of work you do and about your work place?

2. Have you ever been involved or have you worked in the political sector in the past?

3. What is your assessment of the historical role of civil society peace initiatives across the ethnic divide?

4. Track I diplomacy refers to work being done by governments, which is conducted by official representatives of state authorities. Track II diplomacy refers to work being done by Civil Society Organizations (CSOs) or Grassroots groups. What is your assessment of the relationship between Track I and Track II processes with regard to the efforts towards a resolution?

5. What barriers do you think civil society is faced with in relation to peacebuilding and reconciliation efforts?

6. What do you think the role of political leaders should be in relation to the current settlement negotiations?

7. In what ways do you see CSOs contributing to policies, local politics, and peacebuilding in Cyprus?

8. What is your view on what new strategies peace-enhancing agents of civil society need to adopt and pursue to increase their peacebuilding capacity?

9. What suggestions do you have on how the relationship between Track I and Track II diplomacy needs to be structured in order to enhance the overall peace building capacity of the system? 


\section{Appendix B: Questions for those working within the political/public sector}

1. Tell me about the kind of work you do and about your work place?

2. Have you ever been involved or have you worked with Civil Society Organizations in the past?

3. What is your assessment of the historical role of civil society peace initiatives across the ethnic divide?

4. Track I diplomacy refers to work being done by governments, which is conducted by official representatives of state authorities. Track II diplomacy refers work being done by Civil Society Organizations (CSOs) or Grassroots groups. What is your assessment of the relationship between Track I and Track II processes in regard to the efforts towards a resolution?

5. What barriers do you think civil society is faced with in relation to peacebuilding and reconciliation efforts?

6. What do you think the role of political leaders should be in relation to the current settlement negotiations?

7. What barriers do you think political leaders face when it comes to negotiating a settlement?

8. What is your view on what new strategies peace-enhancing agents of civil society need to adopt and pursue to increase their peacebuilding capacity?

9. What suggestions do you have on how the relationship between Track I and Track II diplomacy needs to be structured in order to enhance the overall peacebuilding capacity of the system? 
Appendix C: HSRRC Application Proposal

\section{Portland State University HSRRC Application Proposal}

\section{Project Title and Prospectus}

Title of Proposed Study: Working Title: The Relationship Between Track I

Diplomacy and Civil Society in Cyprus: Peacebuilding and Reconciliation Efforts

Prospectus: In my study, I propose to explore the dynamics between civil society and Track I Diplomacy in Cyprus within the context of peacebuilding and reconciliation during ongoing settlement negotiations.

\section{RESEARCH QUESTION}

1. What is the nature of the relationship between Track I Diplomacy and civil society in the context of peacebuilding and reconciliation in Cyprus?

\section{METHODOLOGY}

I will be analyzing existing quantitative and qualitative raw data in alignment with thematic stages of grounded theory methodology. The theory that has emerged from multiple sources is that there is a lack of structural support in civil society, leading to a lack of direct impact on local and national politics. I will conduct a secondary analysis of data derived from multiple studies then pilot a semi-structured interview protocol to take to political leaders and leaders in Civil Society Organizations (CSOs). After compiling the data, themes, and interview answers, I will further analyze the collaborative results and present them within my thesis.

\section{SUMMARY}

Track I diplomacy refers to government diplomacy, which is conducted by official representatives of state authorities. Track II diplomacy refers to Civil Society Organizations or Grassroots groups. Cyprus is an ethnically divided island, having experienced war and trauma since the 1960s. Effective peacebuilding and reconciliation efforts on both levels are important as political leaders continue settlement negotiations.

A study conducted by the Peace Research Institute of Oslo (PRIO) Cyprus Centre on the impact of peacebuilding work by agencies or groups in 2008 found that there were more factors contributing to the prevention of positive impact on the conflict than there were factors contributing to peacebuilding. The report concluded that peacebuilding is a multi-tracked effort that needs to be exerted on different levels of society in Cyprus along with incentives for both sides to mobilize, incentives that do not currently exist. 
I will explore the impact and relationship of reconciliation and peacebuilding efforts of Track I and II diplomacy by extracting and analyzing data from reports and through interviews. I hope to identify themes between civil society and diplomatic activity, which may inform our understanding about the directions of influence.

\section{Subject Recruitment}

Data will be extracted from Case Studies and Reports found through Civil Society Organizations, third party Organizations, and country reports. Namely, data will be pulled from Civil Society Organizations such as the Peace and Research Institute of Oslo, Cyprus, The Management Centre of the Mediterranean, CIVICUS Civil Society Index Project, The Olive Branch, and the Future Worlds Center. Reports from the Republic of Cyprus (South) and the Turkish Republic of Northern Cyprus (North), will be obtained as well.

After gathering information and pinpointing themes upon analyzing data, I will ask questions (See Appendix A) to individuals active in Civil Society Organizations and within the political sector. I will begin by making face-to-face contact with the appropriate people in each sector and tell them about my research. I will then ask if they would be willing to be interviewed on this subject. If they agree, I will set a time and date to interview them either face-to-face, through the phone, or via Skype. I will ask them about their opinions and observations according to their position. I will be asking at least 5 people for interviews from Civil Society Organizations in the North and at least 5 in the South. I will ask at least 5 people working in the public sector in the North and at least 5 in the South for interviews. The age range differs, but those involved in both sectors on both sides are generally between the ages of 25-55. Ethnic backgrounds will be those of Greek Cypriots and Turkish Cypriots.

Depending upon those that are available and the local distribution of women and male employees, I hope to include an equal ratio of both ethnicities and an equal ratio of women and men. The interview will last no longer than 60 minutes and no less than 15 minutes. The session will be recorded upon signed approval (See Informed Consent form in Appendices) of the participant and then transcribed for coding and review. Participants will be provided with results upon completion of the study.

\section{Screening}

In order to gather the most appropriate data to analyze, I will find political leaders to interview in the North and South of Cyprus. I will also find personnel active in CSOs in the North and South of Cyprus. Because I am interning with a Nongovernmental Organization in Cyprus, I will find these participants based on current connections. Participants from CSOs may include those working at Non-Governmental Organization or Non-profit Organizations, bi-communal agencies or groups, or individuals that have been active in the past with CSOs, agencies, or groups. I will find participants that work 
in the Ministries on both sides, United Nations personnel, and/or European Union personnel that are available to speak within their diplomatic capacities on this subject.

\section{Informed Consent}

Please see Informed Consent form in the Appendices section for your review. As an investigator, I will provide each participant with a copy of the signed Informed Consent form and keep a signed copy of the Informed Consent form for my records, which will be filed in a confidential manner. This Informed Consent form will be given to the participant before being interviewed face-to-face, or will be provided through email prior to a phone/Skype interview.

\section{First-Person Scenario}

I received an email inviting me to be a participant in an interview on Civil Society involvement in the peace process in Cyprus. I replied to the email and noted a date and time I would be available to speak in person for no longer than an hour. I met with the investigator at a coffee shop, signed an Informed Consent form, and was asked if recording the interview was okay with me. I agreed and also retained a copy of the informed consent form for my records. I was asked a series of questions by the investigator. She gave me a copy of the questions that were typed on a piece of paper so I could refer to them during the interview. At the end of the interview, the investigator thanked me for my time and thoughts, and gave me her contact information along with contact information for Portland State University. Once the study was completed, the investigator emailed me written results and asked if I had any questions. The investigator thanked me again for my participation in the study.

\section{Potential Risks and Safeguards}

Potential risks within the political and civil society sectors include recalling disappointments by their leaders or colleagues and having to limit their answers based on their diplomatic/professional capacity.

Safeguards will be in place for all participants by allowing them to choose the most comfortable place to meet for a face-to-face interview, keeping to the approved questions provided during interviews, and ensuring anonymity. Anonymity will be assured through the use of pseudonyms and codes and by keeping all information in a password protected file on my personal computer and a locked file cabinet in the office of the Conflict Resolution Department at Portland State University.

\section{Potential Benefits}

Potential benefits include: Giving participants a voice by including their perspective in this study. This study will also benefit the participants in the long run as further data, understanding, and potential action develops on this subject. Information will add further clarifications to existing data. By pin-pointing themes between various reports, 
as well as providing a theory on how civil society and diplomacy interact with each other to inform peacebuilding and reconciliation efforts, will provide further understanding on how both levels may or may not impact each other, and why.

\section{Records and Distribution}

Participant confidentiality will be maintained through a strict use of assigned codes and pseudonyms in order to identify individual interviews. All materials related to the study such as recordings and notes, will be kept in a locked document file in the office of the Conflict Resolution Department and in a password protected file on the investigator's personal computer. All data will be kept for 5 years following the completion of the study and will be discarded thereafter.

\section{B. Personal Notes and Observations, not to be provided to participant.}

1. I will check off if the participant has experienced or observed any of the following:

a. Activism, of any kind, on the Civil Society level.

b. Involvement with policies or the political arena.

c. Disappointment with leadership or civil society.

d. Connection between diplomacy and civil society in Cyprus.

e. Contributions from CSOs/politics to politics/CSOs.

f. Peace building and reconciliation initiatives in both civil society and political levels.

g. Recommendations of restructuring peace building capacities.

$\mathrm{h}$. Assessments of track one and two diplomacy relationships in Cyprus.

i. Views on obstacles or effectiveness of civil society initiatives in both societies.

\section{Bibliography}

McDonald, J. W., \& Bendahmane, D. R. (1987). Conflict Resolution: Track Two Diplomacy. Washington, DC: US Government Printing Office.

Demetriou, O. and Gürel, A. (2008). Human Rights, Civil Society and Conflict in Cyprus: Exploring the Relationships. Peace Research Institute of Oslo Cyprus Centre, SHUR Working Paper, 3/8. 


\title{
Appendix D: HSRRC Approval Form
}

\section{f马 Portland State}

\author{
Human Subjects Research Review Committee \\ $\begin{array}{ll}\text { Post Office Box 751 } & 503-725-4288 \text { tel } \\ \text { Portland, Oregon 97207-0751 } & 503-725-8170 \text { fax }\end{array}$ \\ hsrrc@lists.pdx.edu
}

July 20,2011

\section{To: $\quad$ Elicia Reed}

From: Mary Oschwald, HSRRC Chair Mnany Johwh thy.

Re: HSRRC approval for your project titled, "The Relationship between Track I Diplomacy and Civil Society in Cyprus" (HSRRC Proposal \# 111798)

Dear Elicia,

In accordance with your request, the Human Subjects Research Review Committee has reviewed your proposal referenced above for compliance with PSU and DHHS policies and regulations covering the protection of human subjects. The Committee is satisfied that your provisions for protecting the rights and welfare of all subjects participating in the research are adequate, and your project is approved. Please note the following requirements:

Changes to Protocol: Any changes in the proposed study, whether to procedures, survey instruments, consent forms or cover letters, must be outlined and submitted to the Committee immediately. The proposed changes cannot be implemented before they have been reviewed and approved by the Committee.

Continuing Review: This approval will expire on July 20, 2012. It is the investigator's responsibility to ensure that a Continuing Review Report on the status of the project is submitted to the HSRRC two months before the expiration date, and that approval of the study is kept current. The Continuing Review Report is available at www.rsp.pdx.edu/compliance_human.php and in the Office of Research and Strategic Partnerships (RSP).

Adverse Reactions and/or Unanticipated Problems: If any adverse reactions or unanticipated problems occur as a result of this study, you are required to notify the Committee immediately. If the issue is serious, approval may be withdrawn pending an investigation by the Committee.

Completion of Study: Please notify the Committee as soon as your research has been completed. Study records, including protocols and signed consent forms for each participant, must be kept by the investigator in a secure location for three years following completion of the study (or per any requirements specified by the project's funding agency).

If you have questions or concerns, please contact the HSRRC in the Office of Research and Strategic Partnerships (RSP) at 503-725-4288, Market Center Building, Room 620.

cc: Robert Gould

Harry Anastasiou 